\title{
Changes in latitude and dominant diazotrophic community alter $\mathbf{N}_{2}$ fixation
}

\author{
Eric J. Raes ${ }^{1, *}$, Anya M. Waite ${ }^{1,2}$, Allison S. McInnes ${ }^{1}$, Hannipoula Olsen ${ }^{1}$, \\ Hoang Minh Nguyen ${ }^{1}$, Nick Hardman-Mountford ${ }^{1,3}$, Peter A. Thompson ${ }^{4}$
}

\author{
${ }^{1}$ The Oceans Institute M047, University of Western Australia, Crawley, 6009 WA, Australia \\ ${ }^{2}$ Alfred Wegener Institute for Polar and Marine Research, Am Handelshafen 12, 27570 Bremerhaven, Germany \\ ${ }^{3}$ CSIRO Marine and Atmospheric Research and Wealth from Oceans national research flagship, Private Bag 5 , \\ Wembley, 6913 WA, Australia \\ ${ }^{4}$ CSIRO Marine and Atmospheric Research and Wealth from Oceans national research flagship, GPO Box 1538 , \\ Hobart, 7001 TAS, Australia
}

\begin{abstract}
The contribution of planktonic diazotrophs to the overall $\mathrm{N}$ budget is a key unknown in the eastern Indian Ocean. Here we investigated the relationships between dissolved inorganic nutrients, phytoplankton pigment composition, microbial community structure, nitrogen fixation rates and the $\delta^{15} \mathrm{~N}$ of fractionated zooplankton samples along the shelf break of Western Australia $\left(32^{\circ}\right.$ to $\left.12^{\circ} \mathrm{S}\right)$ in September 2012. Bulk nitrogen fixation rates declined from $4.8 \mathrm{nmol} \mathrm{l}^{-1} \mathrm{~h}^{-1}$ in the colder and more saline sub-tropical waters at higher latitudes to $1.5 \mathrm{nmol} \mathrm{l}^{-1} \mathrm{~h}^{-1}$ in the warmer and fresher Timor Sea at lower latitudes. A regional bloom of Trichodesmium was identified between $13^{\circ}$ and $9^{\circ} \mathrm{S}$ in the Timor Sea. Trichodesmium-specific $\mathrm{N}_{2}$ fixation rates were $0.05 \pm 0.01 \mathrm{nmol}$ colony $^{-1} \mathrm{~h}^{-1}$. Highest dissolved inorganic nitrogen (DIN) concentrations occurred at the highest $\mathrm{NH}_{4}{ }^{+}: \mathrm{NO}_{3}{ }^{-}$ratios, thereby deviating from the paradigm that greater DIN concentrations come primarily from increased $\mathrm{NO}_{3}{ }^{-}$through advection, mixing or upwelling. Both the microplankton and nanoflagellate fraction declined significantly in warmer waters, with higher DIN concentrations but decreasing $\% \mathrm{NO}_{3}{ }^{-}$. A clear increase in the prokaryotic diagnostic pigment zeaxanthin was seen with increasing temperatures from higher to lower latitudes. The microbial community, measured using automated ribosomal intergenic spacer analysis (ARISA), clustered strongly according to the water mass biogeochemistry including temperature, salinity, DIN and phosphate concentrations ( $\mathrm{p}<0.001$ ). Isotope analysis suggested that injections of low $\delta^{15} \mathrm{~N}$ from $\mathrm{N}_{2}$ fixation lowered the zooplankton $\delta^{15} \mathrm{~N}$ signature of animals up to $\sim 500 \mu \mathrm{m}$ in size and that nearly $47 \%$ of the fixed nitrogen was used by zooplankton $(\leq 500 \mu \mathrm{m}$ fraction) in the Timor Sea.
\end{abstract}

KEY WORDS: Indian Ocean · Nitrogen fixation · Phytoplankton community · Trophic transfer • ARISA · Trichodesmium

Resale or republication not permitted without written consent of the publisher

\section{INTRODUCTION}

Since the $1970 \mathrm{~s}$, it has been recognized that the supply of new nitrogen $(\mathrm{N})$ via $\mathrm{N}_{2}$ fixation to the mixed layer is a key factor regulating the fraction of primary production exported from the surface to the deep ocean (Mague et al. 1974, Bryceson \& Fay 1981,
Capone \& Carpenter 1982). Recent work has emphasised the dominant role of $\mathrm{N}_{2}$ fixation as a source of new $\mathrm{N}$ (and new primary production) in stratified and tropical oceanic ecosystems (Capone \& Knapp 2007, Großkopf et al. 2012). Yet, the importance of $\mathrm{N}_{2}$ fixation in the Indian Ocean remains unclear (Waite et al. 2013). Feedback between $\mathrm{N}_{2}$ fixation and oceanic 
and atmospheric $\mathrm{CO}_{2}$ coupling may be globally important, as $\mathrm{N}_{2}$ fixation rates are likely to increase, due to both enhanced stratification (Hood et al. 2004, Breitbarth et al. 2007) and reduced nutrient fluxes over the pycnoclines (Boyd et al. 2010, Garcia et al. 2011). Estimated $\mathrm{N}_{2}$ fixation inputs to pelagic ecosystems (Westberry \& Siegel 2006, Großkopf et al. 2012) have been predicted to increase above $200 \mathrm{Tg} \mathrm{N} \mathrm{yr}{ }^{-1}$ under these scenarios (Hutchins et al. 2007).

Diazotrophs can utilize dissolved $\mathrm{N}_{2}$ as their inorganic $\mathrm{N}$ source, thereby reducing their dependence on oceanic nitrate, urea or ammonium for growth. This unique ability makes them a potential long-term winner under putative climate change driven reductions in inorganic $\mathrm{N}$ fluxes (Moore \& Doney 2007). Recently, the 2 major oceanic unicellular $\mathrm{N}_{2}$-fixing cyanobacterial groups UCYN-A and Crocosphaera watsonii (group B) have been postulated to have equal or greater abundances and $\mathrm{N}_{2}$ fixation rates than those of the well-known filamentous cyanobacterium Trichodesmium (Goebel et al. 2010, Moisander et al. 2010). Elevated $\mathrm{pCO}_{2}$ concentrations and increased aeolian iron inputs resulting from human induced desertification and climate change could increase $\mathrm{N}_{2}$ fixation rates both for Trichodesmium (35-65\%; Hutchins et al. 2007) and for Crocosphaera ( $24 \%$; Fu et al. 2008). Higher $\mathrm{N}_{2}$ fixation rates and an increase in abundance predicted for the future ocean make it clear that the diazotrophic community plays a significant role in ocean biogeochemistry.

The microbial community transforming nitrogen compounds from organic to inorganic forms also maintains the productivity of some open-ocean oligotrophic ecosystems (Zehr \& Kudela 2011). $\mathrm{N}_{2}$ fixation followed by nitrification within the euphotic zone (Wankel et al. 2007) has been shown to be an important biologically mediated pathway in unproductive and oligotrophic regions (Ward et al. 1989, Yool et al. 2007) such as open-ocean sub-tropical gyres (Mather et al. 2008), enclosed seas like the Mediterranean (Rees et al. 2006) and the Indian Ocean (Thompson et al. 2011b, Waite et al. 2013).

The contribution of planktonic diazotrophs to the overall $\mathrm{N}$ budget is a key unknown in the eastern Indian Ocean, which is one of the most under-studied but strategically important sectors of the globe (Alexander et al. 2012). Our data are the first to (1) quantify $\mathrm{N}_{2}$ fixation rates along the entire west coast of Australia and (2) estimate a first-order regional transfer of low $\delta^{15} \mathrm{~N}$, derived from $\mathrm{N}_{2}$ fixation, into higher trophic levels based on local data in the eastern Indian Ocean. We investigate how sub-micro- molar concentrations and ratio shifts $\left(\mathrm{NH}_{4}{ }^{+}: \mathrm{NO}_{3}{ }^{-}\right)$of dissolved inorganic nitrogen (DIN) mediated by the heterotrophic microbial community impacted the phytoplankton community structure in the relatively warm and oligotrophic waters of the west coast of Australia. In this manuscript, we highlight core biogeographic differences between higher- and lowerlatitude waters around the periphery of an oligotrophic gyre.

\section{MATERIALS AND METHODS}

Our oceanographic study was conducted in the eastern Indian Ocean aboard the RV 'Southern Surveyor' from 6 to 16 September 2012 (early austral spring) along the continental shelf of Western Australia from Fremantle $\left(33^{\circ} \mathrm{S}\right)$ to Darwin $\left(13^{\circ} \mathrm{S}\right)$, covering 1840 nautical miles (Fig. 1a). Continuous underway measurements of sea surface temperature ( $\mathrm{T}$ in ${ }^{\circ} \mathrm{C}$ ) and salinity (S in PSU) were recorded with a SBE 3T Seabird TSG sensor. Water masses were analysed based on their $\mathrm{T}$ and $\mathrm{S}$ properties according to Wijffels et al. (2002), Domingues et al. (2007) and Waite et al. (2013) and compiled into 3 groups: (1) Sub-Tropical Waters (STW): from $33^{\circ}$ to $26.2^{\circ} \mathrm{S}$, with $\mathrm{T}<21^{\circ} \mathrm{C}$ and $\mathrm{S}>35$; (2) East Gyral + Leeuwin Current Waters (EGC+LC): from $26.2^{\circ}$ to $16.3^{\circ} \mathrm{S}$, with $\mathrm{T}$ between 21 and $25.5^{\circ} \mathrm{C}$ and $\mathrm{S} \sim 34.55$; and (3) Timor Sea Waters (TS): from $16^{\circ}$ to $12^{\circ} \mathrm{S}$, with $\mathrm{T}>25.5^{\circ} \mathrm{C}$ and $\mathrm{S}<34.35$. The horizontal current velocity along the ship's track was measured using an RDI $75 \mathrm{kHz}$ Ocean Surveyor acoustic Doppler current profiler (ADCP). The ADCP was set to record to a maximum water column depth of $300 \mathrm{~m}$, and data were averaged in $8 \mathrm{~m}$ depth bins. Processing of ADCP data for this voyage was done with the python version of the University of Hawaii's CODAS system ('pycurrents'). Underway water samples for dissolved inorganic nutrients, chlorophyll a (chl a) concentrations, pigment analysis using highperformance liquid chromatography (HPLC), microplankton taxonomy, microbial diversity using automated ribosomal intergenic spacer analysis (ARISA) and $\mathrm{N}_{2}$ fixation rates were obtained from a continuous flow-through supply $6 \mathrm{~m}$ below the surface.

\section{Nutrient analysis}

Dissolved inorganic nutrient concentrations including phosphate $\left(\mathrm{PO}_{4}{ }^{3-}\right)$, nitrate $\left(\mathrm{NO}_{3}{ }^{-}\right)$, nitrite $\left(\mathrm{NO}_{2}{ }^{-}\right)$ and ammonium $\left(\mathrm{NH}_{4}{ }^{+}\right)$were assayed on a Bran + Luebbe AA3 HR segmented flow analyser, following 


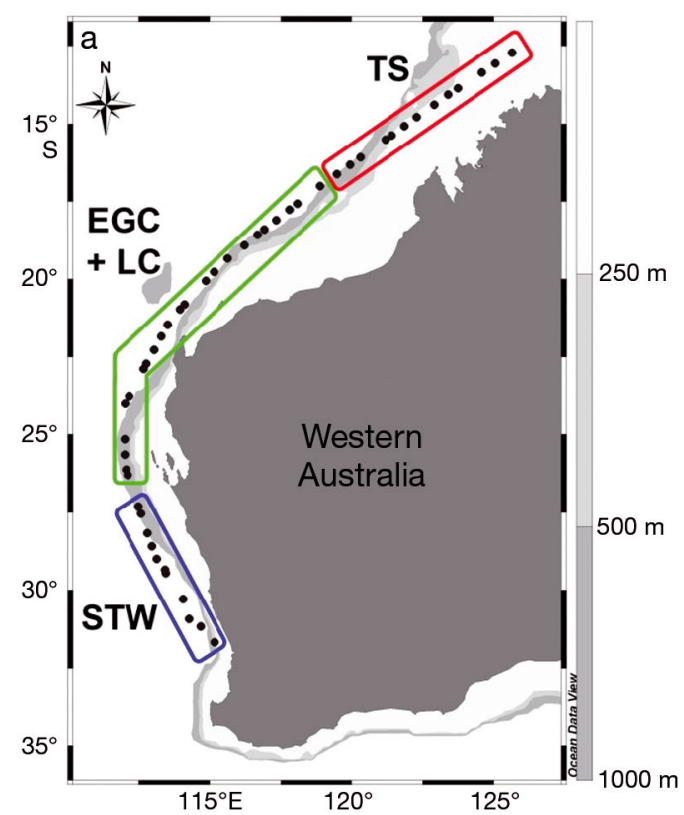

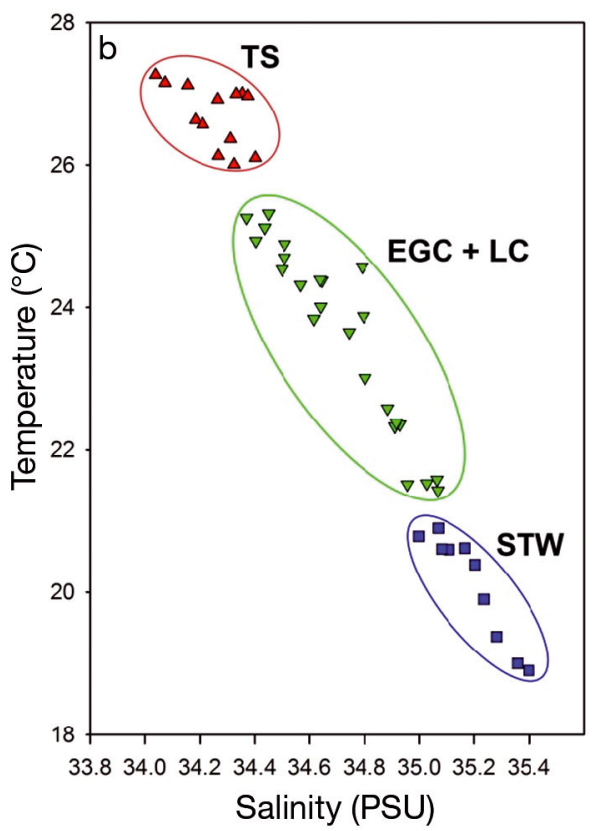

Fig. 1. (a) Area and voyage map with sample locations (black dots) and water masses indicated by rectangles coloured in blue for Sub-Tropical Waters (STW): $31-26.2^{\circ} \mathrm{S}$, temperature $(\mathrm{T})<21^{\circ} \mathrm{C}$, salinity $(\mathrm{S})$ $>35.1$; green for East Gyral + Leeuwin Current Waters (EGC+LC): $24-16.3^{\circ} \mathrm{S}, \mathrm{T}$ $22-25.5^{\circ} \mathrm{C}, \mathrm{S} \sim 34.55$; and red for the Timor Sea (TS): $16-12^{\circ} \mathrm{S}, \mathrm{T}>25.5^{\circ} \mathrm{C}, \mathrm{S}<$ 34.35. (b) Temperature $\left({ }^{\circ} \mathrm{C}\right)$ and salinity (PSU) profile with coloured water masses (blue squares: STW, green downward triangles: EGC+LC, red triangles: TS) standard spectrophotometric methods (Hansen \& Koroleff 2009). $\mathrm{NO}_{3}{ }^{-}$and $\mathrm{NO}_{2}{ }^{-}$were analysed per AA3 method G-172-96 rev15 according to Armstrong et al. (1967) and Grasshoff et al. (2009), with detection limits to $0.015 \mu \mathrm{mol} \mathrm{l}^{-1}$ using $10 \mathrm{~mm}$ flow cells and an LED lamp. Unless elsewhere stated, $\mathrm{NO}_{3}{ }^{-}$is the sum of $\mathrm{NO}_{3}{ }^{-}+\mathrm{NO}_{2}{ }^{-}$. Phosphate was analysed per AA3 method G-297-03 rev3 according to Murphy \& Riley (1962), with detection limits to $0.01 \mu \mathrm{mol} \mathrm{l}^{-1}$ using $10 \mathrm{~mm}$ flow cell and an LED lamp. $\mathrm{NH}_{4}{ }^{+}$was analysed per AA3 method G-327-05 rev4 according to Kérouel \& Aminot (1997), with detection limits to $0.004 \mu \mathrm{mol} \mathrm{l}^{-1}$ using a JASCO fluorometer FP-2020. Dilution series of standard stock solutions were made on the day of analysis. All calibration curves had an $\mathrm{r}^{2}$ of 0.999 . Coefficients of variation were $0.2 \%$ for $\mathrm{NO}_{3}{ }^{-}$ and $\mathrm{NO}_{2}{ }^{-}, 0.4 \%$ for $\mathrm{PO}_{4}{ }^{3-}$ and $0.2 \%$ for $\mathrm{NH}_{4}{ }^{+}$.

\section{Pigment analysis}

For chl a analysis, $0.525 \mathrm{l}$ of sample water was gently filtered via vacuum filtration (pressure drop $<10 \mathrm{kPa}$ ) on $25 \mathrm{~mm}$ Whatman GF/F filters. Chl a extractions were carried out following acidification according to Parsons et al. (1984). Samples were measured on a Turner Trilogy laboratory fluorometer. For HPLC analysis, 41 water samples were filtered (pressure drop $<10 \mathrm{kPa}$ ) on $25 \mathrm{~mm}$ Whatman $\mathrm{GF} / \mathrm{F}$ filters and stored in liquid nitrogen until further analysis. Pigments were determined using HPLC according to the Commonwealth Scientific and Industrial Research Organisation (CSIRO) methods (see Chapter 2 in Hooker et al. 2012). Processed HPLC data were analysed using the diagnostic pigments of the dominant phytoplankton taxa groups (Vidussi et al. 2001, Hirata et al. 2008, Aiken et al. 2009). Pigment data were quality controlled according to Aiken et al. (2009). Our data showed that: (1) the total chl a (TChl a) made up at least $70 \%$ of the total pigment concentration and (2) we had a regression between TChl $a$ and the accessory pigments with a slope of 1.1 and $r^{2}>0.9$. One should note that diagnostic pigment analysis has its ambiguities (e.g. fucoxanthin is a precursor for 19'-butanoyl oxyfucoxanthin and 19'-hexanoyloxyfucoxanthin); for more detail, see Aiken et al. (2009) and Uitz et al. (2006). However, this had only minor implications for our data, as the microplankton represented a small fraction of the total phytoplankton functional types (fraction range: 0.04-0.09).

\section{Picoplankton analysis}

Seawater samples for picoplankton analysis were collected and preserved with molecular grade paraformaldehyde (final concentration $1 \%$ ) and stored at $-80^{\circ} \mathrm{C}$ (Marie et al. 1997, Gasol \& Giorgio 2000). Microbial populations were separated into heterotrophs, Synechococcus-like and Prochlorococcus-like using a Beckman Coulter Gallios flow cytometer 
equipped with $488 \mathrm{~nm}$ and $638 \mathrm{~nm}$ lasers (Liu et al. 2004). Emissions were measured using bandpass filters corresponding to emissions for chl a (em: 680; filter: 695/30), phycoerythrobilin (em: 630; filter: 660/ 30), phycourobilin (em: 577; filter: 575/30) and SYBR@ Green I nucleic acid stain (Molecular Probes; em: 520; filter: 525/30). DNA staining was preformed according to Marie et al. (1997), with slight modifications. Samples were amended with $30 \mathrm{mM}$ tripotassium citrate and SYBR® Green I nucleic acid stain (Molecular Probes) 1:10000 and then incubated for 15 min at $35^{\circ} \mathrm{C}$. Beckman Coulter (cat. no. A91346) Flow-CountTM Fluorospheres were added to each sample for determination of the volume sampled as well as normalization of fluorescence intensity. Post processing determination of groups was performed with Kaluza Flow Cytometry software v1.2 (Beckman Coulter) using various gates and biplots of fluorescence to fully separate microbial sub populations. Samples were initially separated into heterotrophs and autotrophs using forward scatter and chl a fluorescence. Prochlorococcus can be difficult to separate from heterotrophs (Marie et al. 1997), but we successfully separated the 2 populations by analysing the initial heterotroph group in a subsequent biplot using phycoerythrin versus SYBR® fluorescence. Phycourubilin (PUB) versus phycoerythrobilin (PEB) biplots were used to separate autotrophs into the following subgroups: Synechococcus of high PUB:PEB, Synechococcus of low PUB:PEB, Synechococcus with PEB only and Prochlorococcus. Subsequent analyses of these subgroups were performed by plotting these on individual biplots using the various combinations of fluorescence; if separation occurred, these were gated and quantified separately.

\section{Microplankton taxonomy}

The samples for microplankton taxonomy were collected at midnight and sunrise into $0.5 \mathrm{l}$ high-density polyethylene jars, preserved with a Lugol's iodine solution of $7.5 \%$ (Parsons et al. 1984) and stored in the dark until onshore analysis. Onshore, the samples were homogenised by inverting the jars 50 times, after which a whole subsample $(50$ or $60 \mathrm{ml})$ was counted and analysed under a Leica (DM IRB) inverted microscope at $200 \times$ magnification after settling for $\sim 24 \mathrm{~h}$ (Utermöhl 1958). The cell count varied from 352 to 896 cells per subsample, with a total of 43 different species. Each cell was identified to genus level (or closest taxonomic level possible) using iden- tification manuals and books (e.g. Ricard 1987, Tomas et al. 1997, Suthers \& Rissik 2009). Bio-volume of enumerated cells was calculated using basic geometric formulas that were assigned to the different cell shapes in the study of Hillebrand et al. (1999). Where genus-specific calculations were not possible, shapes and measurements were assigned according to taxonomic relatives of the organism and/or to the closest shape according to photos and/or identification books used. Although some cells are known to shrink in Lugol's fixative, this was not taken into account in the bio-volume calculations due to uncertainties of shrink factors for different cells. Carbon content was calculated from the bio-volume using conversion factors. Conversion factors were obtained from Putt \& Stoecker (1989) for ciliates, from Lessard (1991) for dinoflagellates, from Caron et al. (1995) for sarcodines and from Strathmann (1967) for diatoms and silicoflagellate species.

\section{Microbial diversity}

Water samples (2 l each) for ARISA (Fisher \& Triplett 1999, Danovaro et al. 2006) were filtered through $0.2 \mu \mathrm{m}$ Sterivex filters and snap frozen in liquid nitrogen for further analysis. A modified organic (phenol:chloroform:isoamyl based) DNA extraction protocol was used alongside extraction columns from the PowerWater DNA isolation kit (Mo Bio Laboratories) (S. Appleyard pers. comm.), with DNA eluted in $80 \mu \mathrm{l}$ TE buffer. Following sample extraction, DNA was amplified using universal bacterial primers 16S1392F (5'-GYA CAC ACC GCC CGT-3') and a 5 'HEX-labelled version of the reverse primer 23S125R (5'-GGG TTB CCC CAT TCR G-3') which amplified the ITS1 region in the rRNA operon plus approximately 282 bases of the $16 \mathrm{~S}$ and 23S rRNA genes (Hewson \& Fuhrman 2004). PCR amplification conditions included $50 \mu \mathrm{l}$ volumes with $20 \mathrm{ng}$ of DNA, $25 \mu \mathrm{l}$ of GoTaq ${ }^{\circledR}$ Green Master Mix (containing Taq DNA polymerase and dNTPs; Promega), $2 \mu \mathrm{l}$ of bovine serum albumin (Promega) and $1 \mu$ l of each of the $10 \mu \mathrm{mol} \mathrm{l}^{-1}$ primers and water. To monitor extraneous contamination, negative controls containing the PCR mix but without any DNA template were run during each PCR. PCR amplification consisted of an initial denaturation at $94^{\circ} \mathrm{C}$ for $3 \mathrm{~min}$, followed by 35 cycles of denaturation at $94^{\circ} \mathrm{C}$ for $1 \mathrm{~min}$, annealing at $55^{\circ} \mathrm{C}$ for $1 \mathrm{~min} 30 \mathrm{~s}$ and extension at $72^{\circ} \mathrm{C}$ for $1 \mathrm{~min}$ $30 \mathrm{~s}$, with a final extension of $72^{\circ} \mathrm{C}$ for $10 \mathrm{~min}$ in a GeneAmp PCR system 9700 (Applied Biosystems) thermocycler. PCR products were checked on $2.5 \%$ 
agarose-Tris-acetic acid-EDTA (TAE) gels containing SYBR®-Safe (Life Technologies) for DNA staining and visualisation. The reaction was purified using AMPure ${ }^{\mathrm{TM}}$ magnetic beads (Agencourt, Beckman Coulter Life Science) according to the manufacturer's instructions, resuspended in $40 \mu \mathrm{l}$ of TE and then quantified on the Nanodrop. For each ARISA, approximately 25 to $40 \mathrm{ng}$ of purified amplified reaction were mixed with $0.4 \mu \mathrm{l}$ of internal size standard (GS1200-Liz, Applied Biosystems) in deionised formamide and denatured at $94^{\circ} \mathrm{C}$ for $2 \mathrm{~min}$. Denaturing capillary electrophoresis (on a $50 \mathrm{~cm}$ capillary array) was carried out for each purified PCR using an ABI 3130XL genetic analyser (Applied Biosystems). ARISA profiles were analysed using GeneMapper v3.7 (Applied Biosystems). Best fit size calling curves, based on second-order least squares (which compensates for anomalously running fragments in the internal standard) and the local Southern method were determined for each sample and checked for correlation before proceeding with the automated peak scoring. Peak size and area output data were further analysed (window size $=2$ base pairs; shift 0.1 ) by custom R scripts for Auto and Interactive Binner (Ramette 2009).

\section{Zooplankton $\delta^{15} \mathrm{~N}$ and $\delta^{13} \mathrm{C}$}

Fractionated zooplankton samples were obtained from surface Neuston net tows while steaming at 3 knots for $15 \mathrm{~min}$. The Neuston net had a width of $1 \mathrm{~m}$, height of $0.2 \mathrm{~m}$ and a mesh and cod end size of $333 \mu \mathrm{m}$. Upon retrieval, samples were sieved sequentially through mesh sizes of 4000, 2000, 1000, 500, 300 and $100 \mu \mathrm{m}$. Handpicked samples from individual mesh sizes were thoroughly rinsed, and great care was taken to exclude potential Trichodesmium colonies in any of the fractions. Fractionated plankton samples were dried overnight at $60^{\circ} \mathrm{C}$, acidified, dried a second time overnight and homogenised using mortar and pestle. Subsamples of 0.5 to $0.7 \mathrm{mg}$ were weighed and packed into Sercon tin capsules. Determination of $\delta^{15} \mathrm{~N}$ and $\delta^{13} \mathrm{C}$ was carried out using a continuous flow system consisting of a Sercon 20-22 mass spectrometer connected with an Automated Nitrogen Carbon Analyser (ANCA, Sercon). Stable isotope abundances are expressed as the deviation from standards in parts per thousand (\%). Multipoint normalization was used in order to reduce raw values to the international scale (Paul et al. 2007). Standard selection for $\delta^{13} \mathrm{C}$ was as described by Skrzypek et al. (2010).

\section{$\mathrm{N}_{2}$ fixation rates}

We used the 'dissolution method' (Mohr et al. 2010) rather than the 'bubble method' (Montoya et al. 1996) to estimate $\mathrm{N}_{2}$ fixation rates. Buffered YBCII medium (Chen et al. 1996), without addition of vitamins, was filtered $(0.2 \mu \mathrm{m}$ Sterivex filter $)$ prior to degassing (using a heating and stirring block). YBCII medium was transferred into 31 gas-tight Tedlar bags. Oxygen concentrations were checked prior $\left(8.24 \mathrm{mg} \mathrm{l}^{-1}\right)$ and post degassing ( $\left.3.0 \mathrm{mg} \mathrm{l}^{-1}\right)$ to check for completeness of degassing. Tedlar bags were spiked with $0.8 \mathrm{ml}{ }^{15} \mathrm{~N}_{2}$ (98 atom\%; Aldrich) gas per $100 \mathrm{ml}$ YBCII media and shaken vigorously until ${ }^{15} \mathrm{~N}_{2}$ gas dissolved into the media. Incubations started by introducing aliquots of ${ }^{15} \mathrm{~N}_{2}$ tracer-enriched seawater $(2.6 \%$ of the total incubation volume) to the pre-acid washed polycarbonate incubation bottles $(4.57$ 1). Spiked incubation bottles were gently rocked 50 times to enhance mixing of the enriched and incubation water. Incubation bottles were incubated for $24 \mathrm{~h}$ in an on-deck incubator under ambient light conditions and sea surface temperatures. Trichodesmiumspecific $\mathrm{N}_{2}$ fixation rates were conducted on handpicked colonies. Fifty isolated colonies were incubated in $1.25 \mathrm{l}$ bottles with $50 \mathrm{ml}{ }^{15} \mathrm{~N}_{2}$ tracer-enriched seawater. Individual Trichodesmium colony sizes were not determined, as our methodology was based on earlier studies of Capone et al. (2005) and Mulholland et al. (2006), where colony-specific $\mathrm{N}_{2}$ fixation rates were reported without size-specific colony measurements. Orcutt et al. (2001) also noted that although the number of trichomes per colony can vary, the average $\mathrm{N}$ content of puff and tuft colonies at the Bermuda Atlantic Time-series Study (BATS) site remained around $1.8 \mu \mathrm{g}$ per colony, a value close to that reported by Letelier \& Karl (1996) and McCarthy \& Carpenter (1979). Colony-specific $\mathrm{N}_{2}$ fixation rates in our study were calculated based on an average of 200 trichomes per colony, a value that has been used by McCarthy \& Carpenter (1979), Carpenter (1983) and Orcutt et al. (2001). Final micronutrient additions in the incubation bottles were in the order of nano- and picomol $\mathrm{l}^{-1}$ (Table A1 in the Appendix). Experiments were ended by collecting the suspended particles from each bottle by gentle vacuum filtration (pressure drop $<10 \mathrm{kPa}$ ) through a $25 \mathrm{~mm}$ precombusted GF/F filter. Filters were snap frozen in liquid nitrogen and stored at $-80^{\circ} \mathrm{C}$ while at sea. Back in the laboratory on land, filters were acidified and dried overnight at $60^{\circ} \mathrm{C}$. Analysis of the ${ }^{15} \mathrm{~N}_{2}$ incorporation into the particulate organic matter (POM) was carried out using a continuous flow sys- 
tem consisting of a Sercon 20-22 mass spectrometer connected with an ANCA (Sercon) at the West Australian Biogeochemistry Centre at the University of Western Australia (Paul et al. 2007, Skrzypek et al. 2010). Final ${ }^{15} \mathrm{~N}$ atom enrichment was calculated assuming complete dissolution of the gas bubble. The solubility of the $\mathrm{N}_{2}$ concentration in seawater was calculated according to Hamme \& Emerson (2004) for each individual station.

\section{Statistical analysis and mixing model}

Principal component analysis (PCA) was used to explore the transect dataset and to reduce the number of variables in the data matrix. Statistical analyses were performed in $\mathrm{R}$ statistical package v3.0.1 (R Development Core Team 2013). Two- and 1-way ANOVA tests were conducted using the car-package (Fox \& Weisberg 2009) for R with a linear regression model, based on a heteroscedasticity consistent covariance matrix, as sample size was smaller than 250 (Long \& Ervin 2000).

The structural similarity of ARISA datasets was assessed on standardised and transformed data using Bray-Curtis similarity matrices (Spearman correlation, 9999 permutations) and Mantel tests using Primer 6. Microplankton data were assessed using canonical analysis of principal coordinates (CAP) in Primer 6. Permutational multivariate ANOVA (PERMANOVA; Anderson et al. 2008) tests were conducted in Primer 6.

We applied the concept proposed by Montoya et al. (2002) that injections of low $\delta^{15} \mathrm{~N}$ from $\mathrm{N}_{2}$ fixation can lower the zooplankton $\delta^{15} \mathrm{~N}$ signature. A simple linear isotope mixing model was used in this study to estimate a first-order transfer of low $\delta^{15} \mathrm{~N}$ into higher trophic levels based on local data only. For the 2 end points of our model, we used (1) the $\delta^{15} \mathrm{~N}=-1.6 \%$ from the Trichodesmium colonies to represent cyanobacteria $\mathrm{N}_{2}$ fixation and (2) a regional mean ( $\pm \mathrm{SD}$ ) of $\delta^{15} \mathrm{NO}_{3}{ }^{-}=6.6 \pm 0.7 \%$ for the deep $\mathrm{NO}_{3}{ }^{-}$pool in the STW, EGC+LC and TS waters derived from Waite et al. (2007a) and Waite et al. (2013). The latter is similar to oligotrophic oceanic $\mathrm{NO}_{3}{ }^{-}$signatures found in a number of studies globally (Sigman et al. 1997, Brandes et al. 1998, Sigman et al. 2005).

\section{RESULTS}

The transect northwards along the continental shelf of Western Australia (300-1000 m depth con- tours) showed an increase in temperature (19.9 to $27.6^{\circ} \mathrm{C}$ ) and a decrease in salinity (35.36 to 34.04 ) from $31.6^{\circ}$ to $12.7^{\circ} \mathrm{S}$ (Fig. 1a,b). We traversed the colder and more saline STW in the south (high latitudes) and then entered the warmer and fresher TS in the north (low latitudes). ADCP data revealed a southward flow dominating the transect, as expected given the dominance of the Leeuwin Current (LC), with greater current speeds at lowest and highest latitudes $\left(30^{\circ}\right.$ and $\left.12^{\circ} \mathrm{S}, 0.5 \mathrm{~m} \mathrm{~s}^{-1}\right)$ and lowest speeds around $21^{\circ} \mathrm{S}\left(0.2 \mathrm{~m} \mathrm{~s}^{-1}\right)$. Current flows and speeds were as anticipated for the time of the year (Thompson 1984).

\section{Nutrient analysis}

$\mathrm{NH}_{4}{ }^{+}$concentrations increased going to lower latitudes $\left(\mathrm{r}^{2}=0.184\right.$, slope 0.0058, $\left.\mathrm{p}=0.0026, \mathrm{n}=47\right)$. $\mathrm{NO}_{3}{ }^{-}\left(\mathrm{NO}_{3}{ }^{-}+\mathrm{NO}_{2}{ }^{-}\right)$concentrations also increased going to lower latitudes $\left(\mathrm{r}^{2}=0.204\right.$, slope $0.0022, \mathrm{p}=$ $0.0014, \mathrm{n}=47$ ), although $\mathrm{NO}_{2}^{-}$concentrations on their own, with an average of $0.02 \pm 0.02 \mu \mathrm{mol} \mathrm{l}^{-1}$ $( \pm \mathrm{SD})$, showed no significant latitudinal trend $\left(\mathrm{r}^{2}=\right.$ $0.000023, \mathrm{p}=0.975, \mathrm{n}=47$ ). Two stations (D2 and D6) showed relative higher $\mathrm{NO}_{3}{ }^{-}$and $\mathrm{NH}_{4}{ }^{+}$values in the STW (Fig. 2a,b). Both stations also had the highest $\mathrm{NO}_{2}{ }^{-}$concentrations $\left(0.11\right.$ and $0.07 \mu \mathrm{mol} l^{-1}$ for D2 and D6, respectively). The steeper slope for $\mathrm{NH}_{4}{ }^{+}$ $\left(0.0058 \pm 0.0018 \mathrm{SE} \mu \mathrm{mol} \mathrm{l}^{-1}\right.$ per degree latitude $)$ compared to $\mathrm{NO}_{3}^{-}\left(0.0022 \pm 0.0006 \mu \mathrm{mol} \mathrm{l^{-1 }}\right.$ per degree latitude) indicated a significant increase of $21 \%$ of $\mathrm{NH}_{4}{ }^{+}$to the total DIN pool $\left(\mathrm{r}^{2}=0.261, \mathrm{p}<\right.$ $0.001, \mathrm{n}=47$ ). Although the absolute $\mathrm{NO}_{3}{ }^{-}$concentrations increased towards lower latitudes, the corresponding \% contribution of $\mathrm{NO}_{3}{ }^{-}$to total DIN showed a significant decrease by $14 \%$ towards lower latitudes $\left(\mathrm{r}^{2}=0.249, \mathrm{p}<0.001, \mathrm{n}=47\right) . \mathrm{NH}_{4}{ }^{+}$and $\mathrm{NO}_{3}{ }^{-}$ are both driving the increase in DIN at lower latitudes; however, $\mathrm{NH}_{4}{ }^{+}$does so to a larger extent. As a result, highest DIN concentrations occurred at highest $\mathrm{NH}_{4}{ }^{+}: \mathrm{NO}_{3}{ }^{-}$ratios. Total DIN concentrations were significantly different between the STW (higher latitude) and TS (lower latitude) waters (1-way ANOVA $\mathrm{p}<0.05)$. No significant differences were found between the EGC+LC and STW or for the EGC+LC and TS (1-way ANOVAs $\mathrm{p}>0.05$, see Table 1). Average $\pm \mathrm{SE} \mathrm{PO}_{4}{ }^{3-}$ concentrations for the whole transect were $0.11 \pm 0.002 \mathrm{mmol} \mathrm{l}^{-1}(\mathrm{n}=47)$, with no significant latitudinal increase $\left(\mathrm{r}^{2}=0.039, \mathrm{p}=0.056, \mathrm{n}=47\right.$; Fig. $\left.2 \mathrm{c}\right)$. Overall, the N:P ratio increased going to lower latitudes. Two southern stations (D2 and D6) showed outliers with relative higher N:P ratios in the STW. 

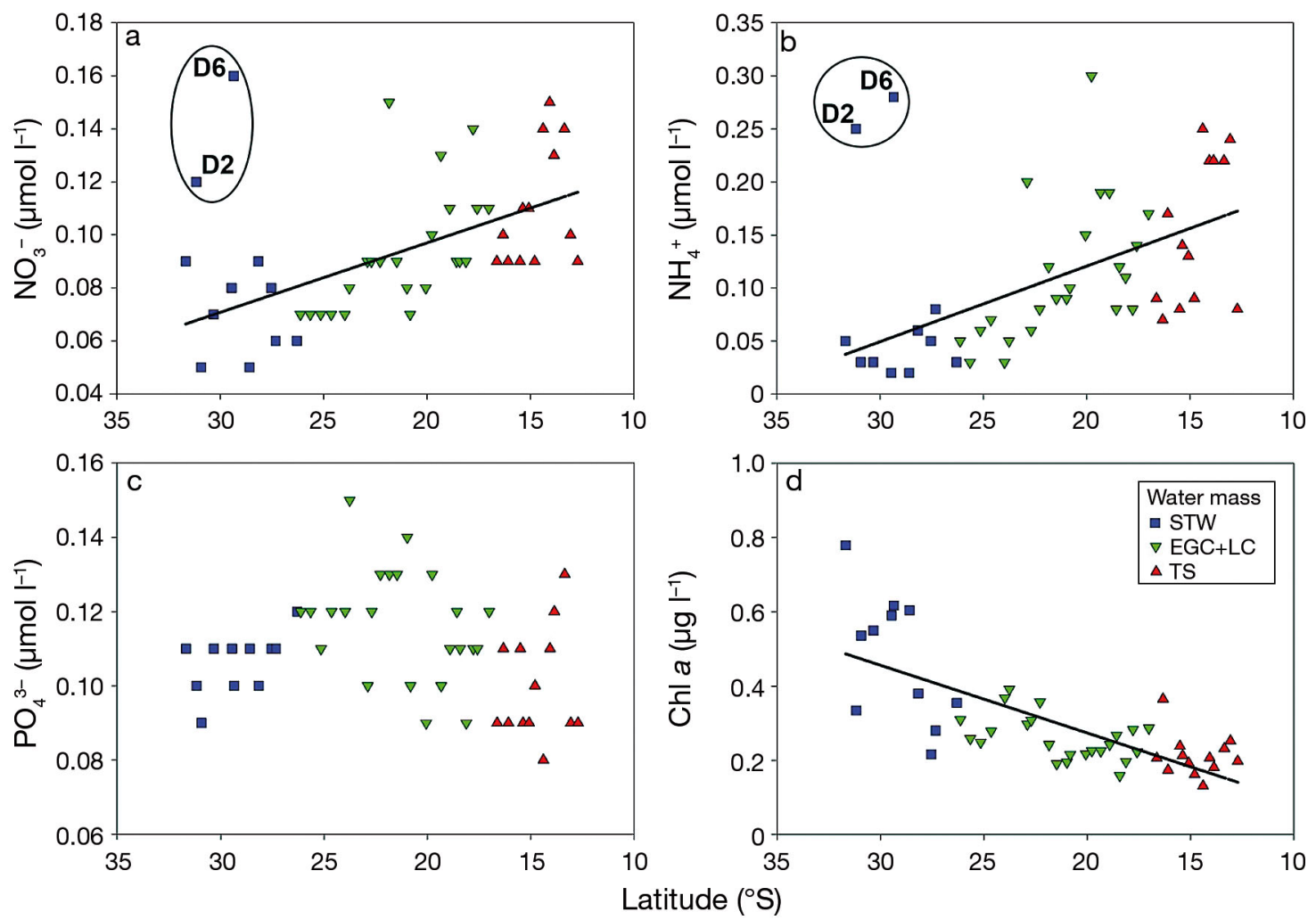

Fig. 2. Relationships between water masses according to latitude with regression lines in black. (a) $\mathrm{NO}_{3}^{-}\left(\mathrm{NO}_{3}{ }^{-}+\mathrm{NO}_{2}{ }^{-}\right)$concentrations ( $\mu \mathrm{mol} \mathrm{l} \mathrm{l}^{-1}$ ); (b) $\mathrm{NH}_{4}{ }^{+}$concentrations $\left(\mu \mathrm{mol} \mathrm{l^{-1 }}\right.$ ); (c) $\mathrm{PO}_{4}{ }^{3-}$ concentrations $\left(\mu \mathrm{mol} \mathrm{l}{ }^{-1}\right)$; (d) chl a concentrations $\left(\mu \mathrm{g} \mathrm{l} \mathrm{l}^{-1}\right.$ ). $\mathrm{NO}_{3}{ }^{-}$and $\mathrm{NH}_{4}{ }^{+}$outliers at stations D2 and D6 also had the highest $\mathrm{NO}_{2}{ }^{-}$values for the whole voyage $\left(0.11\right.$ and $0.07 \mu \mathrm{mol} \mathrm{l}^{-1}$, respectively) and are postulated to be associated with local nitrification and mesoscale eddy features. Water masses coloured in blue squares for Sub-Tropical Waters (STW, water temperature $<21^{\circ} \mathrm{C}$ ); green downward triangles for East Gyral + Leeuwin Current $\left(\mathrm{EGC}+\mathrm{LC}, 21-25.5^{\circ} \mathrm{C}\right)$ and red triangles, Timor Sea $\left(\mathrm{TS},>25.5^{\circ} \mathrm{C}\right)$

$\mathrm{N}: \mathrm{P}$ values were $1.8 \pm 1.6<1.9 \pm 0.8<2.9 \pm 1.0$ for the STW, EGC+LC and TS, respectively. N:P ratios were only significantly different between the STW and TS (1-way ANOVA, $\mathrm{p}<0.05)$. Although N:P ratios nearly doubled going north, the values were still lower than the Redfield ratio of 6.6:1 (Redfield 1958), such that overall the West Australian coast could still potentially be $\mathrm{N}$ limited. A PERMANOVA (testing all the nutrient variables against the individual water masses) showed significant differences between all water masses (STW and EGC+LC, p = 0.034; EGC+ LC and TS, $p=0.007$; TS and STW, $p=0.003$ ). Temperature, salinity, nutrient and N:P ratio data for the transect are summarized in Table 1.

\section{Pigment analysis}

A pairwise multiple comparison (Dunn's Method) between the water masses showed significantly higher chl a concentrations in the STW compared to the TS $(p<0.05)$, higher chl a concentrations in the
STW compared to the EGC+LC $(\mathrm{p}<0.05)$ but no difference between the EGC+LC and TS ( $p>0.05$; Fig. 2d). Relatively higher inorganic N:P ratios coincided with low chl a values along the transect. Chl a data for the transect are summarized in Table 1.

The photosynthetic microplankton component, defined by the diagnostic pigments of the dominant phytoplankton taxa groups (see 'Materials and methods'), showed a declining trend towards lower latitudes $\left(\mathrm{r}^{2}=0.708\right.$; slope $-0.0047 \pm 0.0007 \mathrm{SE} ; \mathrm{p}<$ 0.0001), corresponding to warmer waters and declining $\mathrm{NO}_{3}{ }^{-}$concentrations (Fig. 3a). The microplankton community declined $-0.4 \%$ per $1^{\circ}$ latitude north $(\sim 111 \mathrm{~km})$ in the STW. This declining trend increased farther north to $-0.5 \%$ per $1^{\circ}$ latitude for the EGC+LC and $-1.6 \%$ per $1^{\circ}$ latitude for TS. Pairwise multiple comparison (Tukey's tests) for the microplankton showed significant differences between STW and EGC+LC $(p<0.001)$ and between the STW and TS $(p<0.001)$. No significant differences were found between EGC+LC and TS ( $p=0.234$; Table 2). The nanoflagellate component, although to a much 
greater extent than the microplankton component, showed a similar declining trend towards lower latitudes $\left(r^{2}=0.851 ;\right.$ slope $\left.-0.0279 \pm 0.0028 \mathrm{SE}_{i} \mathrm{p}<0.0001\right)$. This amounted to a $-2.4 \%$ per $1^{\circ}$ latitude for the STW and $-2.8 \%$ per $1^{\circ}$ latitude for both the EGC+LC and TS (Fig. $3 b)$. The median nanoflagellate proportions showed significant differences between all water masses (Tukey's tests: $p<0.0001$ between the STW and TS, $p<0.0001$ between the STW and EGC+LC and $\mathrm{p}=0.005$ between the EGC+LC and TS; Table 2). A clear increase in the prokaryotic community was seen from higher to lower latitudes $\left(\mathrm{r}^{2}=0.848\right.$; slope $\left.0.0326 \pm 0.0032 \mathrm{SE}_{\text {; }} \mathrm{p}<0.0001\right)$, with increasing temperatures and increasing $\mathrm{NH}_{4}{ }^{+}$concentrations. This revealed an increase of $2.8 \%$ per $1^{\circ}$ latitude for the high-latitude water mass, and a $3.3 \%$ increase per $1^{\circ}$ latitude for the low-latitude water masses, respectively (Fig. 3c). The median prokaryotic proportions were significantly different between all the water masses (Tukey's tests: $\mathrm{p}<0.0001$ between STW and TS, $p$ $<0.0001$ for STW and EGC+LC and $\mathrm{p}=0.005$ for EGC+LC and TS; Table 2). A PERMANOVA, combining the microplankton, nanoflagellate and prokaryote abundance, showed significant differences between STW and EGC+LC waters $(p=0.004)$, between STW and TS $(p=$ $0.001)$ and between EGC+LC and TS $(p=0.004)$.

\section{Picoplankton analysis}

Flow cytometry data showed that Prochlorococcus spp. were least abundant in cooler, sub-tropical waters $(0.5 \times$

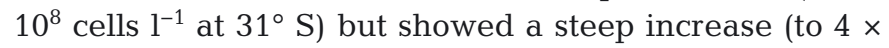

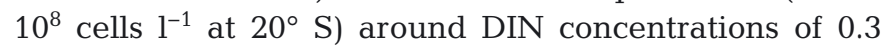
$\mu \mathrm{mol} \mathrm{l}^{-1}$ in the EGC+LC. Although DIN concentrations were below $1 \mu \mathrm{mol} \mathrm{l}^{-1}$, Prochlorococcus spp. concentrations started to tail off around $0.5 \mu \mathrm{mol} \mathrm{l^{-1 }}$. Overall Synechococcus spp. abundance was greater than Prochlorococcus spp. abundance $\left(0.5-6.5 \times 10^{8}\right.$ cells $\left.1^{-1}\right)$. The Synechococcus: Prochlorococcus ratio was lowest in STW. This ratio veered further into 2 different relationships, one with a low and one with a high Synechococcus:Prochlorococcus ratio. A Bray-Curtis similarity test showed a clear separation of 2 different possible Synechococcus and Prochlorococcus clades in all water masses (Fig. 4). There was no significant trend for the prokaryotic community, which included all non-phototrophs and was derived from the SYBER $®$ stain, with latitude $\left(\mathrm{r}^{2}=0.0019, \mathrm{p}=0.84, \mathrm{n}=\right.$ $24)$ or among the individual water masses (1-way ANOVA: $\mathrm{p}=0.47$ ). There was also no significant trend in the prokaryotic and autotrophic (Prochlorococcus + Synechococcus + pico-eukaryotes) ratio with latitude $\left(\mathrm{r}^{2}=\right.$ $\left.1.3 \times 10^{-5}, \mathrm{p}=0.98, \mathrm{n}=24\right)$ or among the water masses $(1-$ way ANOVA: $p=0.66$ ). 


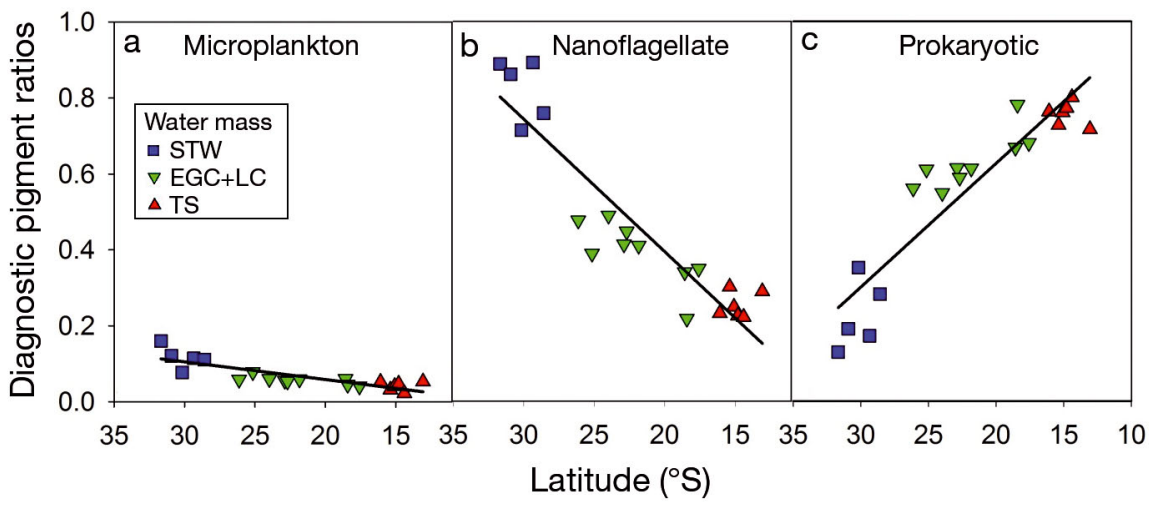

Fig. 3. Diagnostic pigment analysis from a latitudinal transect along the West Australian Shelf with linear regression lines in black: (a) microplankton, (b) nanoflagellates and (c) prokaryotic pigment fractions. Water masses coloured in blue squares for Sub-Tropical Waters (STW, water temperature $<21^{\circ} \mathrm{C}$ ); green downward triangles for East Gyral + Leeuwin Current (EGC+ $\mathrm{LC}, 21-25.5^{\circ} \mathrm{C}$ ) and red triangles for the Timor Sea $\left(\mathrm{TS},>25.5^{\circ} \mathrm{C}\right)$
Table 2. Ratios (mean \pm SD) of the phytoplankton communities calculated by pigment analysis (see 'Materials and methods') and summarized according to water masses (STW: Sub-Tropical Waters, EGC+LC: East Gyral Current + Leeuwin Current; TS: Timor Sea)

\begin{tabular}{|lccc|}
\hline Water mass & $\begin{array}{c}\text { Microplankton } \\
(\mathrm{n}=5)\end{array}$ & $\begin{array}{c}\text { Nanoflagellate } \\
(\mathrm{n}=9)\end{array}$ & $\begin{array}{c}\text { Prokaryote } \\
(\mathrm{n}=6)\end{array}$ \\
\hline STW & $0.09 \pm 0.03^{\mathrm{a}, \mathrm{b}}$ & $0.46 \pm 0.20^{\mathrm{a}, \mathrm{b}}$ & $0.45 \pm 0.23^{\mathrm{a}, \mathrm{b}}$ \\
EGC+LC & $0.05 \pm 0.01^{\mathrm{b}}$ & $0.30 \pm 0.05^{\mathrm{b}, \mathrm{c}}$ & $0.65 \pm 0.06^{\mathrm{b}, \mathrm{c}}$ \\
TS & $0.04 \pm 0.01^{\mathrm{a}}$ & $0.21 \pm 0.04^{\mathrm{a}, \mathrm{c}}$ & $0.75 \pm 0.03^{\mathrm{a}, \mathrm{c}}$ \\
${ }^{\mathrm{a}} \mathrm{p}<0.001,1$ 1-way ANOVA Tukey between STW and TS \\
${ }^{\mathrm{b} p}<0.001$ 1-way ANOVA Tukey between STW and EGC+LC \\
${ }^{\mathrm{c}} \mathrm{p}<0.05$, 1-way ANOVA Tukey between STW and EGC+LC \\
\hline
\end{tabular}

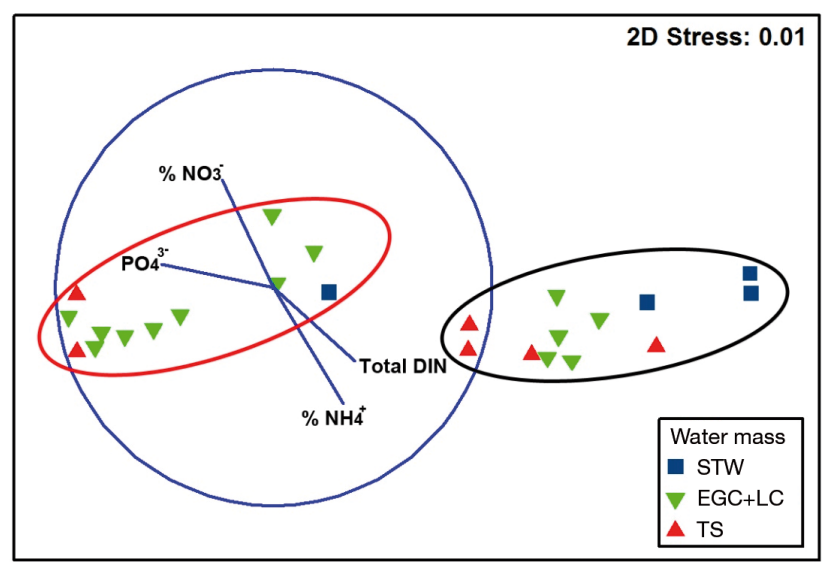

Fig. 4. Synechococcus and Prochlorococcus abundance based on Bray-Curtis similarity resemblance with a Spearman rank vector overlay restriction of 0.49 and square root pre-treatment. Red and black circles indicate different clades (Rocap et al. 2002). Samples were categorised into 3 water masses; coloured in blue squares for Sub-Tropical Waters (STW, water temperature $<21^{\circ} \mathrm{C}$ ); green downward triangles for East Gyral + Leeuwin Current (EGC+LC, $21-25.5^{\circ} \mathrm{C}$ ) and red triangles for the Timor Sea (TS, $>25.5^{\circ} \mathrm{C}$ ). DIN: dissolved inorganic nitrogen

\section{Microplankton taxonomy}

Microscopic analysis revealed that the microplankton community compromised 26 families and 2 higher taxonomic levels from the kingdom Rhizaria. The Dinophyceae including large gymnoids and other Dinophyceae (e.g. Gyrodinium spp., Prorocentrum spp.) were the most abundant microplankton, accounting for more than $50 \%$ of the microplankton bio-volume at all stations. A CAP did not reveal a clear clustering of microplankton composition, but a more gradual trend, as the water masses gradually changed in temperature and salinity with latitude (Fig. 5). Gyrodinium spp. clearly correlated with different water masses to their closely related gymnoid species. Although temperature increased and salinity decreased going farther north, there was no significant trend for carbon contribution from microplankton across the latitudinal gradient. Most of the carbon contribution came from the large gymnoids, except for stations at 26 and $24^{\circ} \mathrm{S}$, where other microplankton (Rhizaria, Chrysophyceae, Euglenophyceae, Oligotrichida and Choreotrichia) made up the major carbon biomass. This was caused by a higher number of Strombidium spp. there than at other stations. During our study, a regional bloom of the $\mathrm{N}_{2}$-fixing cyanophyte Trichodesmium was identified as distinctive yelloworange surface slicks between 13 and $9^{\circ} \mathrm{S}$. This was a regional-scale feature during the voyage $(\sim 50 \times$ 50 km; Fig. 6a,b).

\section{Microbial diversity}

ARISA distinguishes microbial communities based on differences in length heterogeneity in the ribosomal intergenic spacer region between the $16 \mathrm{~S}$ and 


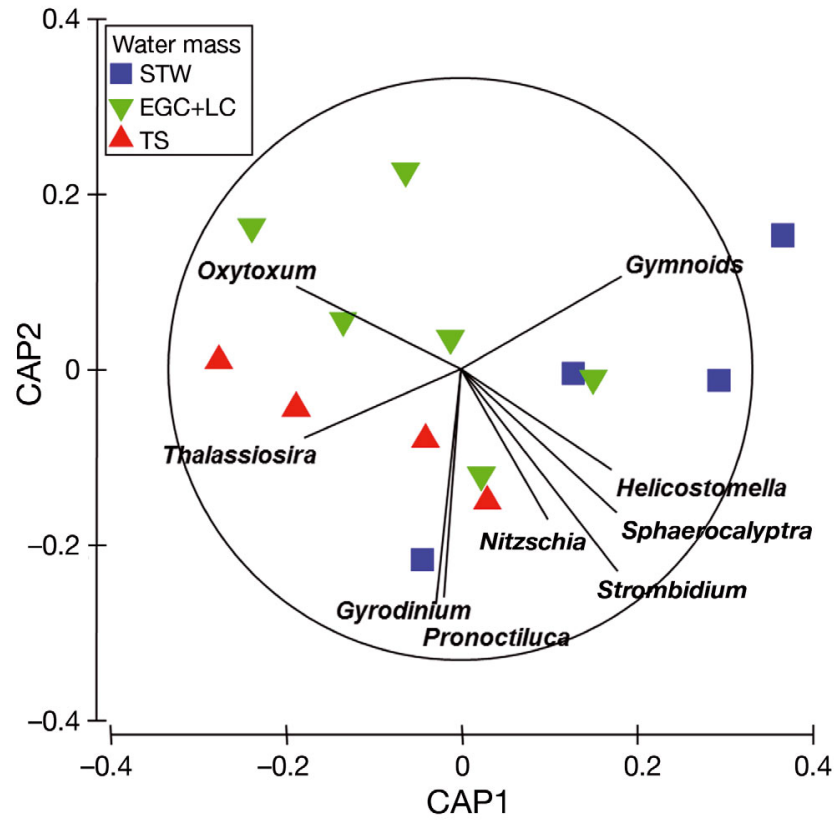

Fig. 5. Canonical analysis of principal coordinates based on Bray-Curtis similarity resemblance matrix of microplankton count data with a Spearman rank vector species overlay (restriction of 0.56 and square root pre-treatment). Samples were categorised into 3 water masses; coloured in blue squares for Sub-Tropical Waters (STW, water temperature $<21^{\circ} \mathrm{C}$ ); green downward triangles for East Gyral + Leeuwin Current $\left(\mathrm{EGC}+\mathrm{LC}, 21-25.5^{\circ} \mathrm{C}\right.$ ) and red triangles for the Timor Sea $\left(\mathrm{TS},>25.5^{\circ} \mathrm{C}\right)$

23S rRNA genes in the rRNA operon. The ARISA analyses enabled us to directly and rapidly compare the microbial diversity and community composition along a latitudinal gradient in this study. The structural similarity of ARISA datasets were assessed on standardised (by total) and transformed (square root) data using Bray-Curtis similarity matrices and showed a strong difference between STW, EGC+LC and TS. A Pearson rank vector overlay (0.56) highlighted the importance and close relationship between microbial community structure and $\mathrm{NH}_{4}{ }^{+}$ at low latitudes and $\mathrm{NO}_{3}{ }^{-}$and $\mathrm{PO}_{4}{ }^{3-}$ concentrations at high latitudes (Fig. 7). A Mantel test confirmed the significant relationship between the microbial community structure and water mass biogeochemistry including temperature, salinity, DIN and phosphate concentrations (Mantel test, $\mathrm{p}<0.001$ ). A PERMANOVA, combining all the operational taxonomical units of the ARISA data, showed a significant difference between STW and TS $(p=0.013)$ but no significant difference between STW and EGC+LC $(p=0.124)$ or between EGC+LC and TS $(p=0.834)$.

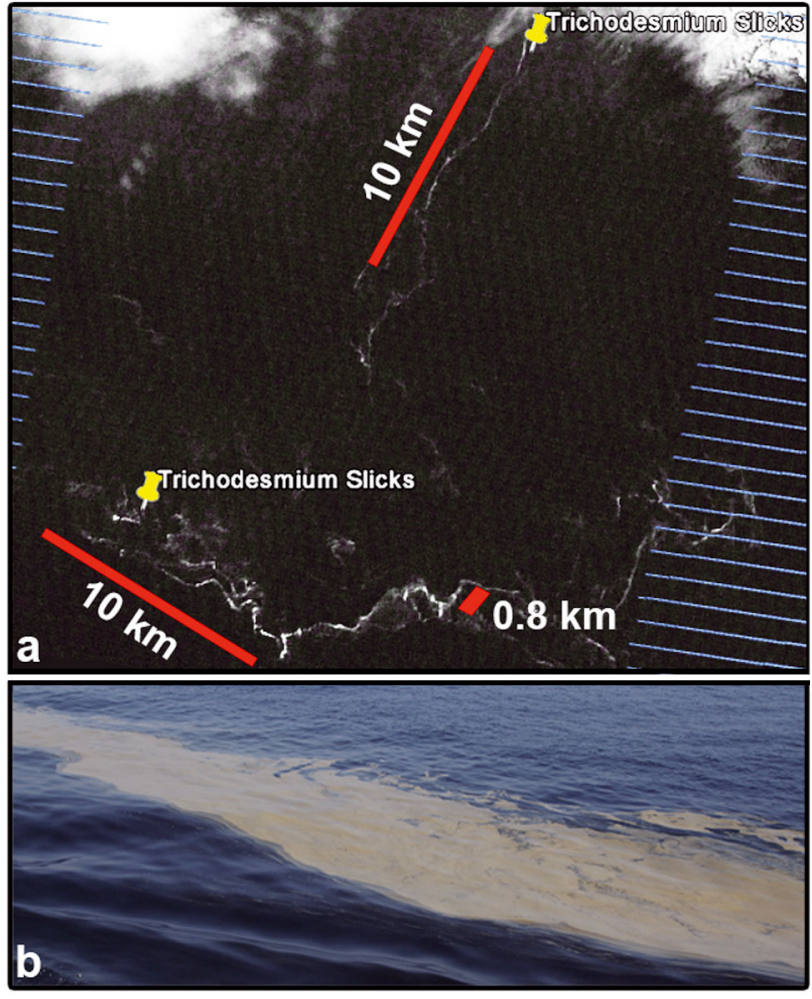

Fig. 6. Regional-scale Trichodesmium bloom in the Timor Sea between $13^{\circ}$ and $9^{\circ} \mathrm{S}$. (a) Enhanced Landsat 7 near infra-red image at $15^{\circ} 5^{\prime} \mathrm{S}$ and $123^{\circ} 45^{\prime} \mathrm{E}$, with surface Trichodesmium slicks. (b) On-board photo of surface Trichodesmium slick at $13^{\circ} 32^{\prime} \mathrm{S}$ and $125^{\circ} 27^{\prime} \mathrm{E}$

\section{$\mathbf{N}_{2}$ fixation rates}

Nitrogen fixation was detected along the entire West Australian coastline. Average $\pm \mathrm{SD}$ bulk $\mathrm{N}_{2}$ fixation rates in the STW were $4.78 \pm 1.16 \mathrm{nmol} \mathrm{l}^{-1} \mathrm{~h}^{-1}$ $(\mathrm{n}=7), 3.18 \pm 1.33 \mathrm{nmol} \mathrm{l}^{-1} \mathrm{~h}^{-1}(\mathrm{n}=16)$, in the EGC+LC waters and $1.48 \pm 0.65 \mathrm{nmol} \mathrm{l}^{-1} \mathrm{~h}^{-1}(\mathrm{n}=8)$ in the TS (Fig. 8a). Median $\mathrm{N}_{2}$ fixation rates showed a significant decline from high to low latitudes. All water masses were distinctively different (1-way ANOVAs: STW and TS, $\mathrm{p}<0.001$; STW and EGC+ LC, $\mathrm{p}=0.014$; TS and EGC+LC, $\mathrm{p}=0.006$ ). Colonyspecific mean $\pm \mathrm{SD} \mathrm{N}_{2}$ fixation rates were $0.05 \pm$ $0.01 \mathrm{nmol}^{\text {colony }} \mathrm{H}^{-1} \mathrm{~h}^{-1}(\mathrm{n}=3)$ in the TS. These rates compare to those reported by Carpenter \& Price (1977), McCarthy \& Carpenter (1979) and Orcutt et al. (2001). Capone et al. (1998) recorded up to 17000 trichomes $l^{-1}$ in surface slicks in the northern Indian Ocean. When each colony is assumed to have 200 filaments (McCarthy \& Carpenter 1979), we calculated 85 colonies $\mathrm{l}^{-1}$, resulting in Trichodesmiumspecific $\mathrm{N}_{2}$ fixation rates of $4.62 \pm 1.36 \mathrm{nmol} \mathrm{l}^{-1} \mathrm{~h}^{-1}$. These rates are 3 times higher compared to the bulk 
$\mathrm{N}_{2}$ fixation rates $\left(1.48 \pm 0.65 \mathrm{nmol}^{-1} \mathrm{~h}^{-1}\right)$ at the same latitude. Yet bulk $\mathrm{N}_{2}$ fixation rates in the STW match Trichodesmium-specific $\mathrm{N}_{2}$ fixation rates.

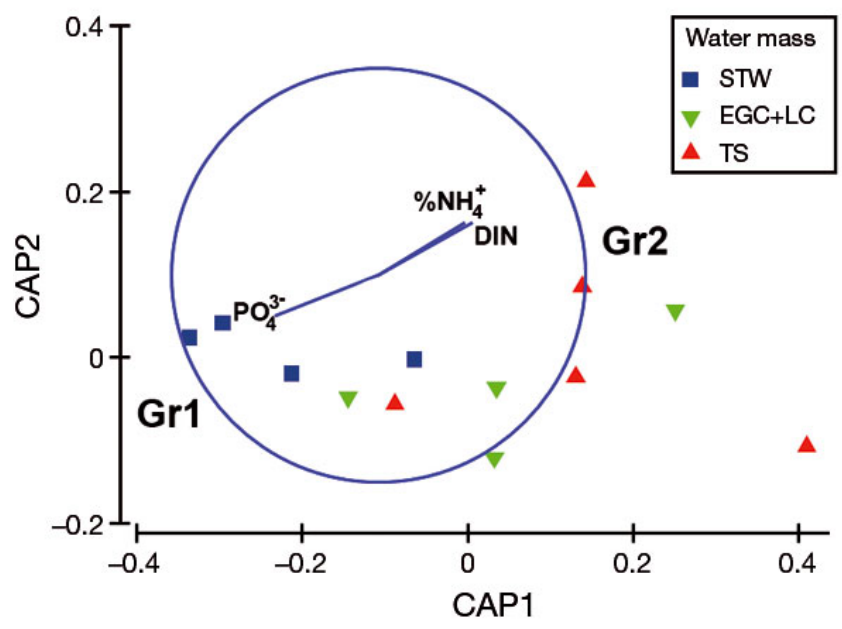

Fig. 7. Canonical analysis of principal coordinates based on Bray-Curtis similarity resemblance matrix of microbial community (ARISA) data with a Spearman rank vector nutrient overlay (restriction of 0.48 and square root pre-treatment). Samples were categorised into 3 water masses, coloured in blue squares for Sub-Tropical Waters (STW, water temperature $<21^{\circ} \mathrm{C}$ ); green downward triangles for East Gyral + Leeuwin Current $\left(\mathrm{EGC}+\mathrm{LC}, 21-25.5^{\circ} \mathrm{C}\right)$ and red triangles for the Timor Sea $\left(\mathrm{TS},>25.5^{\circ} \mathrm{C}\right.$ ). Genetic grouping 1 (Gr1) is associated with deep nutrient fluxes (increase in $\mathrm{NO}_{3}{ }^{-}$and $\mathrm{PO}_{4}{ }^{3-}$ ) and $\mathrm{Gr} 2$ is associated with a lowering of $\delta^{15} \mathrm{~N}$ and increase in $\mathrm{NH}_{4}{ }^{+}$and total dissolved inorganic nitrogen (DIN)

\section{Zooplankton $\delta^{15} \mathrm{~N}$ and $\delta^{13} \mathrm{C}$}

The zooplankton $\delta^{15} \mathrm{~N}$ values generally increased with size fraction but decreased in TS in proximity to the Trichodesmium bloom (Fig. 8b). To determine whether these differences and their primary covariates were significant, we used PCA. Variables included temperature, phosphate, chl a concentrations, fractionated zooplankton samples and prokaryotic diagnostic pigments. The PCA indicated that the first 2 PCs explained $86.26 \%$ of the total variance $(67.44 \%$ and $18.82 \%$, respectively). The main contributing variables to PC1 included temperature and prokaryotic community abundance (0.512 and 0.503 loadings, respectively). PC2 showed a significant positive loading with the zooplankton $\delta^{15} \mathrm{~N}$ size fractions (0.878) and a negative loading, although to a much lesser extent, of chl a concentrations $(-0.350)$. PC1 indicated significant negative correlations between temperature and prokaryote concentration $(-0.458)$, and between $\mathrm{chl}$ $a$ and phosphate concentrations $(-0.469)$. Conversely, chl a concentrations decreased from high to low latitudes. PC2 highlights the separation between small-sized zooplankton $(\leq 500 \mu \mathrm{m})$ caught between $12.4^{\circ}$ and $12.7^{\circ} \mathrm{S}$ and the rest of the data set (Fig. 8a). These samples were found to have negative $\delta^{15} \mathrm{~N}$ compositions, possibly indicating the presence of an $\mathrm{N}_{2}$-fixing community that is consumed as a food source.
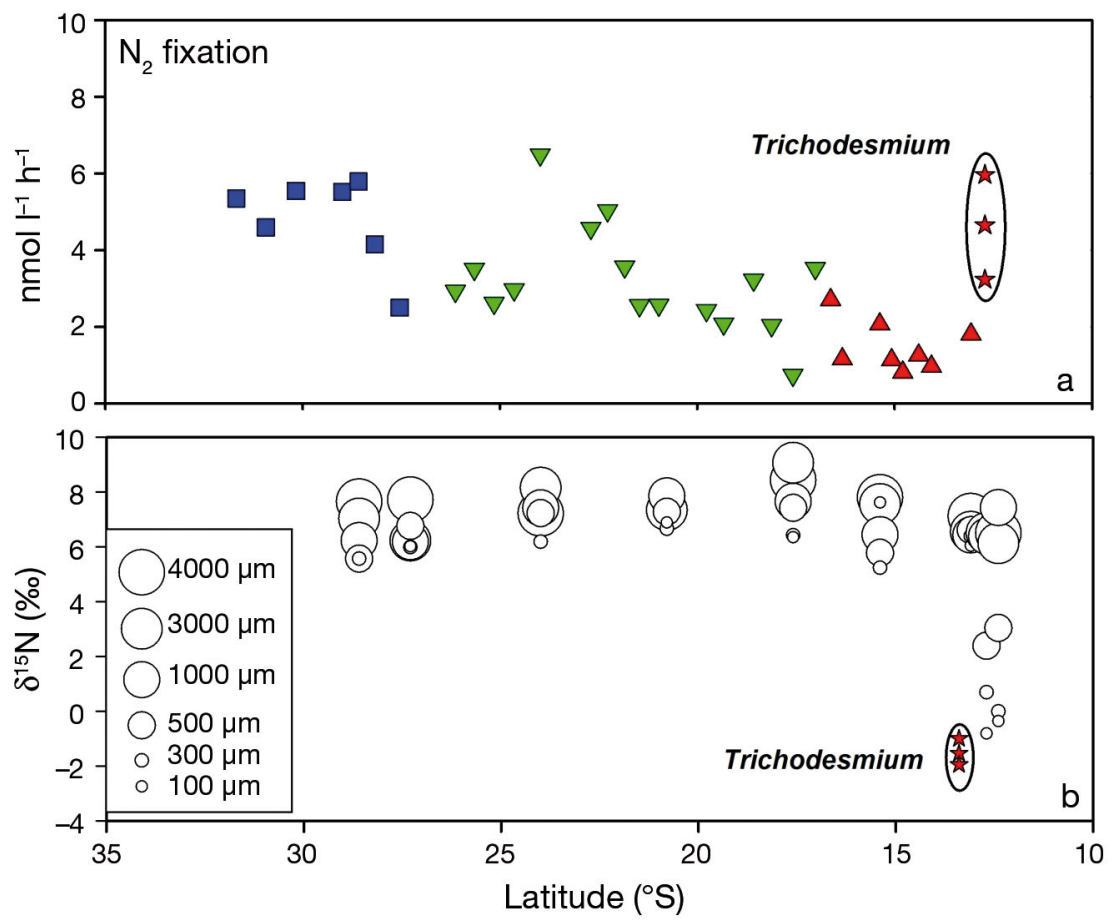

Fig. 8. (a) Bulk $\mathrm{N}_{2}$ fixation and Trichodesmium-specific $\mathrm{N}_{2}$ fixation rates

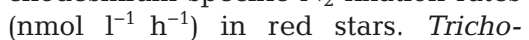
desmium $\mathrm{N}_{2}$ fixation rates of $0.05 \pm$ $0.01 \mathrm{nmol} \mathrm{colony}^{-1} \mathrm{~h}^{-1}$ were converted

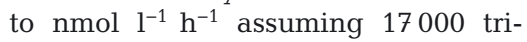
chomes $\mathrm{l}^{-1}$ in surface water (Capone et al. 1998) and 200 filaments colony ${ }^{-1}$ (McCarthy \& Carpenter 1979). Water masses coloured in blue squares for Sub-Tropical Waters (STW, water temperature $<21^{\circ} \mathrm{C}$ ); green downward triangles for East Gyral + Leeuwin Current $\left(\mathrm{EGC}+\mathrm{LC}, 21-25.5^{\circ} \mathrm{C}\right)$ and red triangles for the Timor Sea (TS, $\left.>25.5^{\circ} \mathrm{C}\right)$. (b) Isotope signature $\left(\delta^{15} \mathrm{~N}\right)$ of fractionated zooplankton samples obtained from Neuston net tows (4000 $<2000<1000<500<300<100 \mu \mathrm{m}$ ), Trichodesmium colonies excluded. Trichodesmium data (red stars highlighted with black circle) were obtained by handpicking individual colonies 
A simple linear isotope mixing model with 2 end points showed that $80 \pm 4 \%$ of the $100 \mu \mathrm{m}$ fraction in the northern latitudes is likely to be grazing, directly or indirectly, on a pool of low $\delta^{15} \mathrm{~N}$ (derived from $\mathrm{N}_{2}$ fixation).

The fractional contribution from $\mathrm{N}_{2}$ fixation declined towards greater size classes (higher trophic levels) to $79 \pm 2 \%$ for the $300 \mu \mathrm{m}$ and $47 \pm 6 \%$ for the $500 \mu \mathrm{m}$ fraction in the northern latitudes. At the higher latitudes, the zooplankton size classes (up to $500 \mu \mathrm{m}$ ) are all over $94 \%$ based on a $\delta^{15} \mathrm{~N}$ pool derived from deep $\mathrm{NO}_{3}{ }^{-}$(see Table A2 in the Appendix).

\section{DISCUSSION}

In our study, relative high DIN concentrations in the south eastern Indian Ocean occurred at the highest $\mathrm{NH}_{4}{ }^{+}$concentrations, differing from the classic paradigm where large DIN concentrations come primarily from $\mathrm{NO}_{3}{ }^{-}$via mixing or classic upwelling (Kokkinakis \& Wheeler 1987). While new production is always enhanced by the vertical flux of $\mathrm{NO}_{3}{ }^{-}$, the export f-ratio according to Dugdale \& Goering (1967) is no longer valid when the highest DIN concentrations occur at highest $\mathrm{NH}_{4}{ }^{+}: \mathrm{NO}_{3}{ }^{-}$ratios. This is likely to occur when $\mathrm{N}_{2}$ fixation dominates new $\mathrm{N}$ input (Gruber \& Sarmiento 1997, Großkopf et al. 2012) and/or when nitrification occurs within or near the euphotic zone (here referred to as 'shallow nitrification'; see Lipschultz et al. 2002, Yool et al. 2007 and Thompson et al. 2011b).

Latitude itself does not control ecological processes, yet in this study we described biological pathways along a spatial gradient as a suite of physical and biogeochemical parameters strongly correlated with latitude. We show that the total DIN concentrations increased significantly at lower latitudes, and that the highest DIN concentrations occurred at the highest $\mathrm{NH}_{4}{ }^{+}: \mathrm{NO}_{3}{ }^{-}$ratios. The latitudinal $\mathrm{NO}_{3}{ }^{-}$and $\mathrm{NH}_{4}{ }^{+}$concentration and ratio shift observed during our brief snapshot is accompanied by a gradient in phytoplankton community structure from a microand nanoflagellate-dominated ecosystem to a prokaryotic system heading equatorward, despite the apparent increase in available $\mathrm{N}$. The 3.5-fold increase in the prokaryotic diagnostic pigment zeaxanthin (representative of prokaryotic cyanobacteria) from higher to lower latitudes is similar in scale to the 5-fold increase (across similar latitudes) reported by Thompson et al. (2011a). Injection of new $\mathrm{N}$ as $\mathrm{NH}_{4}{ }^{+}$ in northern waters is potentially subjected to rapid uptake and recycling. This, in combination with rapid growth rates at higher temperatures (Eppley 1972), is likely to lead to much more rapid processing of $\mathrm{N}$ by the lower-latitude planktonic community. The ubiquitous dominance of large non-photosynthetic gymnoids (Dinophyceae) in the microplankton along the entire West Australian shelf suggests that prokaryotes are always subject to high grazing rates (Paterson et al. 2007), although their exact role requires further exploration.

The conceptual model postulated by Thompson et al. (2011b) links the source of $\mathrm{NH}_{4}{ }^{+}$concentrations at higher latitudes to an increase in grazing pressure after/during the austral autumn bloom when $\mathrm{NO}_{3}{ }^{-}$ concentrations are higher (Alcaraz et al. 1994). Injections of $\mathrm{NO}_{3}{ }^{-}$occur via erosion of the pycnocline during the autumn acceleration of the Leeuwin Current (Koslow et al. 2008, Rousseaux et al. 2012). Waite et al. (2013) suggested that these increased $\mathrm{NH}_{4}{ }^{+}$concentrations can be derived, at least in part, from $\mathrm{N}_{2}$ fixation which is in fact a more likely and continuous source of new $\mathrm{N}$, especially near the surface. Evidently both processes are not mutually exclusive. However, in this study we were able to confirm the findings of high bulk $\mathrm{N}_{2}$ fixation rates $\left(4.5 \mathrm{nmol}^{-1}\right.$ $\mathrm{h}^{-1}$ ) at higher latitudes (to $32^{\circ} \mathrm{S}$ ). It is interesting to note that our data showed a latitudinal decrease in bulk $\mathrm{N}_{2}$ fixation rates towards warmer waters (from 4.5 to $1.24 \mathrm{nmol}^{-1} \mathrm{~h}^{-1}$ ). Low bulk $\mathrm{N}_{2}$ fixation rates in the TS were compensated by the injection of new $\mathrm{N}$ from a Trichodesmium bloom. Our data show that unicellular diazotrophs declined when Trichodesmium was present in warmer, tropical waters, suggesting a diazotrophic community shift when Trichodesmium is present. To date we have no additional molecular data to show the presence of other diazotrophs such as diatom-diazotroph associations, coccoid forms or UCYN-A that could be responsible for the injections of new $\mathrm{N}$ at these lower latitudes from our transect. However, our HPLC and microscopic data showed a declining trend for the photosynthetic microplankton, and we can therefore, carefully, exclude an increasing presence of any diatom-diazotroph associations in the northern latitudes. We therefore summarize cautiously that the increase of fixation at higher latitudes is likely to be caused by unicellular fixation, while Trichodesmium is the prime candidate at lower latitudes. Iron conservation strategies by unicellular diazotrophs have been shown to provide an ecological advantage in low-iron environments of the open ocean (Saito et al. 2011), whereas protein level responses of Trichodesmium under iron starvation have been shown to 
down-regulate $\mathrm{N}_{2}$ fixation rates (Richier et al. 2012). The trace level iron additions during our experiments ranged between 10 and $17 \mathrm{nmol} \mathrm{l}^{-1}$ and although these concentrations are at the lowest end of those reported by Richier et al. (2012), it is important to keep in mind how iron availability influences the physiology and the adjacent fixation of $\mathrm{N}_{2}$ of diazotrophs (Berman-Frank et al. 2007, Rubin et al. 2011).

Despite the documented prevalence of Trichodesmium in the open ocean since the 19th century (Capone et al. 1997), and recent identification from space of vast surface distributions covering hundreds of kilometres (Subramaniam et al. 2001, McKinna et al. 2011, Waite et al. 2013), it remains unclear exactly how much Trichodesmium contributes to new production in the global ocean, particularly in the poorly-studied Indian Ocean. Up-scaling the average bulk $\mathrm{N}_{2}$ fixation rates from our data gives us insight in the relative importance of the biogeochemical impact of the unicellular diazotrophs and Trichodesmium along our transect. Rodier \& Le Borgne (2008, 2010) measured Trichodesmium densities up to $1.2 \times 10^{7}$ trichomes $1^{-1}$. For our calculations, we used Trichodesmium densities of 17000 trichomes $1^{-1}$ reported by Capone et al. (1998) in the North Indian Ocean. We calculated an $\mathrm{N}_{2}$ fixation flux for Trichodesmium of $6.9 \times 10^{10} \mu \mathrm{mol} \mathrm{h}^{-1}$ for a $50 \times 50 \mathrm{~km}$ bloom (down to $6 \mathrm{~m}$ depth). The relative importance of Trichodesmium in the TS becomes a smaller proportion of the total diazotrophic community (i.e. Trichodesmium is diluted out) when one begins to upscale and the bloom area is reduced relative to bulk rates. Because bulk $\mathrm{N}_{2}$ fixation rates declined with latitude, Trichodesmium remains a prime candidate for $\mathrm{N}$ injection in the Tropics (TS). Yet, our data highlight the overall importance of the unicellular diazotrophs across the study region, particularly in the south. Our high bulk $\mathrm{N}_{2}$ fixation rates support the postulated hypothesis by Goebel et al. (2010) and Moisander et al. (2010) that oceanic unicellular $\mathrm{N}_{2}$-fixing cyanobacteria can have equal or greater $\mathrm{N}_{2}$ fixation rates than Trichodesmium. 'New' primary productivity, calculated from the bulk $\mathrm{N}_{2}$ fixation rates and using a $\mathrm{C}: \mathrm{N}$ ratio of 6.3 from our data $(\mathrm{n}=31)$, declined from $361 \mu \mathrm{g} \mathrm{C} \mathrm{m}^{-3} \mathrm{~h}^{-1}$ (STW) to $240 \mu \mathrm{g} \mathrm{C} \mathrm{m}^{-3} \mathrm{~h}^{-1}$ (EGC+LC) and to $112 \mu \mathrm{g} \mathrm{C} \mathrm{m} \mathrm{C} \mathrm{h}^{-1}$ (TS). These data compare to the surface production levels reported by Hanson et al. (2005). Our data show that it is likely that $\mathrm{N}_{2}$ fixation contributes significantly (up to $50 \%$ ) to new production in the eastern Indian Ocean. However, intense seasonal and spatial sampling is needed to resolve the different temporal and physical scales at which Trichodesmium and the unicellular $\mathrm{N}_{2}$-fixing cyanobacteria operate. Trichodesmium blooms have been reported to be temporally short (Bar-Zeev et al. 2013) and cover substantially large areas (Subramaniam et al. 2001), but unicellular $\mathrm{N}_{2}$-fixing cyanobacteria have larger depth distributions and cover higher latitudes (Moisander et al. 2010).

If the $\mathrm{NH}_{4}{ }^{+}$source for the DIN we measured is an injection of organic $\mathrm{N}$ into the planktonic ecosystem via $\mathrm{N}_{2}$ fixation, it essentially enters the system as 'new' reduced $\mathrm{N}$. We would then expect the low $\delta^{15} \mathrm{~N}$ signatures from the diazotrophic community to move into the organic matter of higher trophic levels (Montoya et al. 2002). Trichodesmium has been identified as a potential species involved in passing the low $\delta^{15} \mathrm{~N}$ signature of fixed nitrogen up the food chain. This is thought to occur directly by mesozooplankton grazing (O'Neil \& Roman 1992, 1994), which is mostly done by Macrosetella (McKinnon et al. 2003, 2008) and indirectly, via cell leakage and microbial processing and through phytoplankton uptake of the regenerated $\mathrm{N}$ of $\mathrm{N}_{2}$ fixed products (Montoya et al. 2002, Wannicke et al. 2010, Waite et al. 2013). Our linear isotope mixing model suggested that nearly $50 \%$ of the fixed nitrogen from Trichodesmium is used and incorporated into the $\leq 500 \mu \mathrm{m}$ fraction at lower latitudes. The data from this northern part of our voyage revealed that biological $\mathrm{N}_{2}$ fixation appears to be a plausible mechanism for introducing $\delta^{15} \mathrm{~N}$-depleted compounds into Indian Ocean food webs regionally across the north-west of Australia. In the southern part of the transect, however, where bulk $\mathrm{N}_{2}$ fixation rates were higher, the direct biogeochemical impact of fixed-nitrogen transfer into mesozooplankton seemed to be negligible. We postulate that the sub-tropical waters have a longer food web and microbial loop associated with the $\mathrm{N}_{2}$-fixing pico-cyanobacteria (see Wannicke et al. 2010). This prolonged foodweb structure is likely to move $\mathrm{N}$ into microzooplankton grazers, rather than mesozooplankton. Even when mesozooplankton is able to access this $\mathrm{N}$, the large number of intermediate trophic levels, which consequently lead to more fractionation steps, will have increased the $\delta^{15} \mathrm{~N}$ of the organic matter. The lack of clear transfer of low $\delta^{15} \mathrm{~N}$ into mesozooplankton at the higher latitudes could also be due to a more continuous flux of $\mathrm{NO}_{3}{ }^{-}$ through eddy pumping (Waite et al. 2007b) and higher selective grazing rates on the larger proportion of microphytoplankton (diatoms and dinoflagellates) we observed by the zooplankton community (Malone 1971, Gaul \& Antia 2001, Wannicke et al. 2010). In contrast, in the north we support the hypothesis of a shorter food web, where direct feed- 
ing by mesozooplankton on the larger Trichodesmium colonies consequently lowers the $\delta^{15} \mathrm{~N}$ of their organic matter.

Although we lack measurements of $\mathrm{NH}_{4}{ }^{+}$oxidation and nitrification rates, we propose a conceptual hypothesis of food web structure, based on our data and literature data (Fig. 9). The eastern Indian Ocean is a region where surface (mixed layer) $\mathrm{NO}_{3}{ }^{-}$is most often undetectable (Pearce \& Pattiaratchi 1999) such that shallow nitrification can measurably structure $\mathrm{NO}_{3}{ }^{-}$concentrations above the pycnocline (Yool et al. 2007, Thompson et al. 2011b, Paterson et al. 2013, Waite et al. 2013). The microbial community from our transect shifted from a distinct genetic grouping (Gr1) in the south associated with deep nutrient fluxes (increase in $\% \mathrm{NO}_{3}{ }^{-}$and $\mathrm{PO}_{4}{ }^{3-}$ ) and to another genetic grouping (Gr2) in the north associated with a lower $\delta^{15} \mathrm{~N}$ of organic matter, increase in $\% \mathrm{NH}_{4}{ }^{+}$and increase in total DIN. This change in microbial community structure is likely to mediate shifts in the $\mathrm{N}$ processing of the community (Zehr \& Kudela 2011).
In particular, we speculate that nitrification of the $\mathrm{NH}_{4}{ }^{+}$injections is likely to be more important in the northern group (Gr2), as nitrification of POM derived from $\mathrm{N}_{2}$ fixation has been identified in the top $200 \mathrm{~m}$ of EGC+LC waters (Waite et al. 2013).

We speculate that the POM, derived from $\mathrm{N}_{2}$ fixation in the north-eastern Indian Ocean, has the potential to be remineralised and transported southward (to higher latitudes) by the Leeuwin Current while undergoing sequential oxidation of $\mathrm{NH}_{4}{ }^{+}$to $\mathrm{NO}_{2}{ }^{-}$and $\mathrm{NO}_{3}{ }^{-}$(Zehr \& Ward 2002, Waite et al. 2013). Coupled measurements of $\delta^{15} \mathrm{~N}$, and $\delta^{18} \mathrm{O}$ of $\mathrm{NO}_{3}{ }^{-}$would allow determination of the $\mathrm{N}$ cycling processes that occur in the upper ocean, as the process of nitrification is potentially a source of isotopically light $N$ (Wankel et al. 2007). The presence of nitrification genes of the genus Nitrobacter sp. at the surface and independent of water masses along the entire visited track (E. J. Raes unpubl.), could support our proposed conceptual model. Remineralisation (Ward 2008) is further optimized when the organic

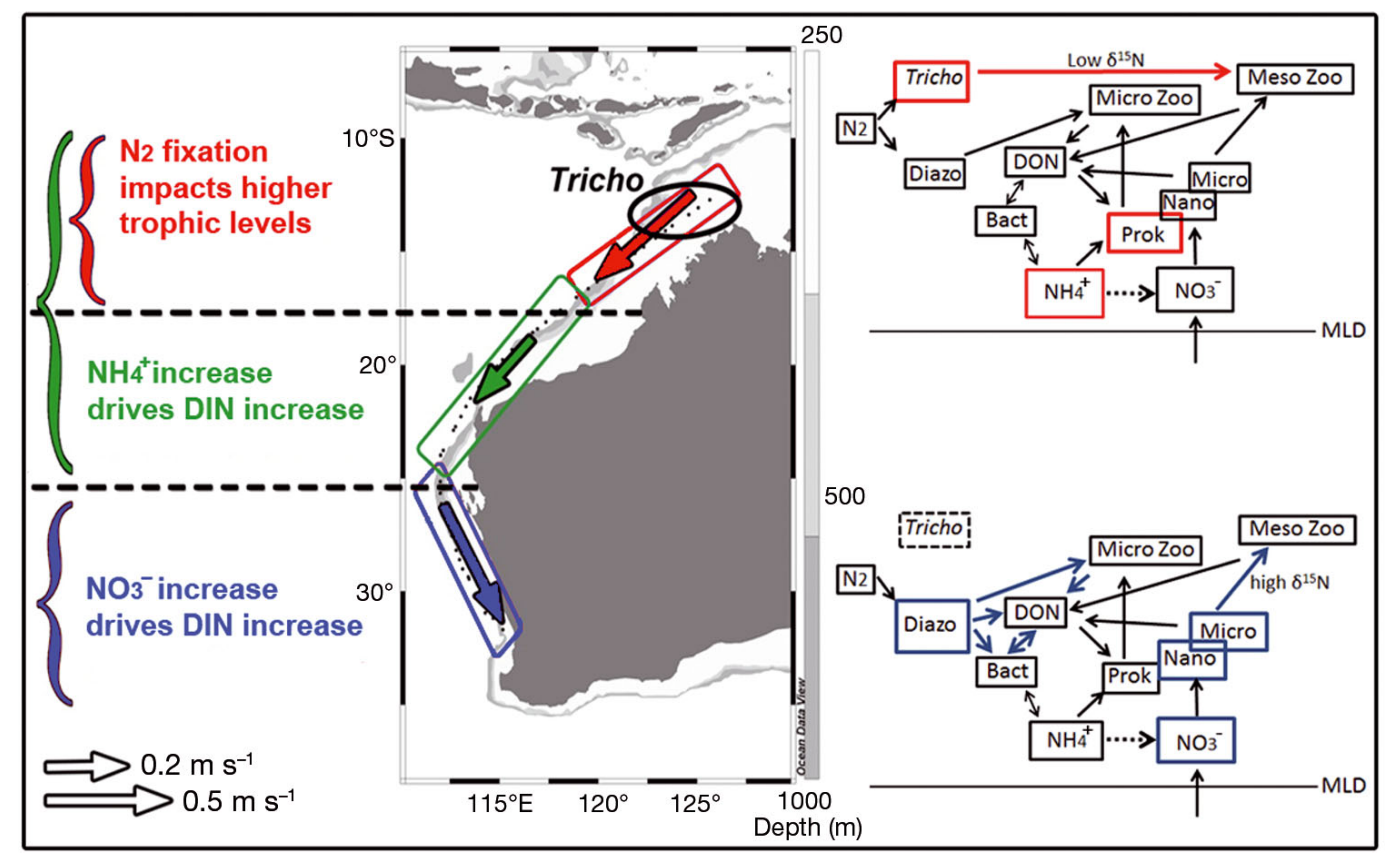

Fig. 9. Left panels: Conceptual hypothesis/model showing fixed $\mathrm{N}$ with low $\delta^{15} \mathrm{~N}$ signatures moving south from the original source in the Timor Sea. The dissolved inorganic nitrogen (DIN) data show that highest DIN concentrations occur at highest $\mathrm{NH}_{4}{ }^{+}: \mathrm{NO}_{3}{ }^{-}$ratios. Arrows indicating in situ current velocity from Acoustic Doppler Current Profiler (ADCP) data. Colour coding: blue for Sub-Tropical Waters (STW), green for East Gyral + Leeuwin Current (EGC+LC) and red for the Timor Sea (TS). Trichodesmium bloom shown by black circle and bathymetry shown on right side of the regional map. Top right panel: Conceptual hypothesis of a possible food web showing the community relationships in the TS. Red boxes highlight major dominant pools. Red arrow highlights the incorporation of low $\delta^{15} \mathrm{~N}$ into mesozooplankton. Bottom panel shows the conceptual hypothesis of possible relationships in STW. Blue boxes show major pools. Blue arrows from the pico $\mathrm{N}_{2}$-fixing cyanobacteria (Diazo) highlight a possible longer foodweb (more fractionation). Greater nano- and micro-fractions (supported by deep $\mathrm{NO}_{3}^{-}$) transfer higher $\delta^{15} \mathrm{~N}$ into mesozooplankton. Dotted arrow indicates nitrification in the euphotic zone (see Lipschultz et al. 2002, Yool et al. 2007, Thompson et al. 2011b). DON: dissolved organic nitrogen, MLD: mixed layer depth. Note: diagrams are nonexclusive considering there are more than the shown possible $\mathrm{N}$ transformations 
matter has the potential to accumulate at strong interfaces (MacIntyre et al. 1995, Doostmohammadi et al. 2012, Waite et al. 2013) such as low dissolved oxygen high nitrate (LDOHN) layers. The deeper boundary of the low salinity layers in these LDOHN layers, running along the entire West Australian shelf (Thompson et al. 2011b), could be a hotspot for remineralisation and nitrification of POM. Recent work by Waite et al. (2013) suggested that up to $90 \%$ of unassimilated $\mathrm{NO}_{3}{ }^{-}\left(\mathrm{NO}_{3}{ }^{-}\right.$with isotopically light $\left.\delta^{15} \mathrm{~N}\right)$ found in surface waters in the northern part of the south-eastern Indian Ocean is likely to have originated from $\mathrm{N}_{2}$ fixation (Waite et al. 2013).

It is clear that more work has to be done to unravel how the diazotrophic community and in situ biogeochemical processes (such as sinking/subduction, decomposition and nitrification of the biomass) interrelate towards primary productivity in the eastern Indian Ocean. It will be important to elucidate the temporal and physical scale of Trichodesmium blooms and regional $\mathrm{N}_{2}$ fixation rates of picocyanobacteria, as our data showed that $\mathrm{NH}_{4}{ }^{+}$injections from $\mathrm{N}_{2}$ fixation and from microbial remineralisation have a potentially profound impact on marine community structure.

Acknowledgements. We thank the captain and Marine National Facility crew of the 'Southern Surveyor' for their technical assistance while at sea. This research was made feasible because Dr. Chris Wilcox gave us the opportunity to piggyback onto his voyage. We thank Dr. Peter Strutton for funding the pigment analysis and acknowledge the valuable knowledge of Peter Hughes during the nutrient analysis. E.J.R. received an Australian Postgraduate scholarship from the University of Western Australia and a CSIRO Wealth from Oceans postgraduate top-up scholarship. Additional supporting grants came from A.M.W. We are very grateful for the insights and comments from 3 anonymous reviewers.

\section{LITERATURE CITED}

Aiken J, Pradhan Y, Barlow R, Lavender S, Poulton A, Holligan P, Hardman-Mountford N (2009) Phytoplankton pigments and functional types in the Atlantic Ocean: a decadal assessment. Deep-Sea Res II 56:899-917

Alcaraz M, Saiz E, Estrada M (1994) Excretion of ammonia by zooplankton and its potential contribution to nitrogen requirements for primary production in the Catalan Sea (NW Mediterranean). Mar Biol 119:69-76

Alexander D, Ameer A, Rupakjyoti B, Fernando YJSN and others (2012) Indian Ocean: a sea of uncertainty. Future Directions International, Perth

Anderson M, Gorley RN, Clarke RK (2008) Permanova+ for Primer: guide to software and statistical methods. Primer-E, Plymouth

Armstrong FAJ, Stearns CR, Strickland JDH (1967) The measurement of upwelling and subsequent biological process by means of the Technicon Autoanalyzer ${ }^{\circledR}$ and associated equipment. Deep Sea Res Oceanogr Abstr 14: 381-389

Bar-Zeev E, Avishay I, Bidle KD, Berman-Frank I (2013) Programmed cell death in the marine cyanobacterium Trichodesmium mediates carbon and nitrogen export. ISME J 7:2340-2348

Berman-Frank I, Quigg A, Finkel ZV, Irwin AJ, Haramaty L (2007) Nitrogen-fixation strategies and Fe requirements in cyanobacteria. Limnol Oceanogr 52:2260-2269

> Boyd PW, Strzepek R, Fu F, Hutchins DA (2010) Environmental control of open-ocean phytoplankton groups: now and in the future. Limnol Oceanogr 55:1353-1376

Brandes JA, Devol AH, Yoshinari T, Jayakumar DA, Naqvi SWA (1998) Isotopic composition of nitrate in the central Arabian Sea and eastern tropical North Pacific: a tracer for mixing and nitrogen cycles. Limnol Oceanogr 43: 1680-1689

Breitbarth E, Oschlies A, LaRoche J (2007) Physiological constraints on the global distribution of Trichodesmium-effect of temperature on diazotrophy. Biogeosciences 4:53-61

Bryceson I, Fay P (1981) Nitrogen fixation in Oscillatoria (Trichodesmium) erythraea in relation to bundle formation and trichome differentiation. Mar Biol 61:159-166

Capone DG, Carpenter EJ (1982) Nitrogen fixation in the marine environment. Science 217:1140-1142

> Capone DG, Knapp AN (2007) Oceanography: a marine nitrogen cycle fix? Nature 445:159-160

Capone DG, Zehr JP, Paerl HW, Bergman B, Carpenter EJ (1997) Trichodesmium, a globally significant marine cyanobacterium. Science 276:1221-1229

> Capone DG, Subramaniam A, Montoya JP, Voss M and others (1998) An extensive bloom of the $\mathrm{N}_{2}$-fixing cyanobacterium Trichodesmium erythraeum in the central Arabian Sea. Mar Ecol Prog Ser 172:281-292

Capone DG, Burns JA, Montoya JP, Subramaniam A and others (2005) Nitrogen fixation by Trichodesmium spp.: an important source of new nitrogen to the tropical and subtropical North Atlantic Ocean. Global Biogeochem Cycles 19:GB2024, doi: 10.1029/2004GB002331

> Caron DA, Michaels AF, Swanberg NR, Howse FA (1995) Primary productivity by symbiont-bearing planktonic sarcodines (Acantharia, Radiolaria, Foraminifera) in surface waters near Bermuda. J Plankton Res 17:103-129

Carpenter EJ (1983) Nitrogen fixation by marine Oscillatoria (Trichodesmium) in the world's oceans. In: Carpenter EJ, Capone DG (eds) Nitrogen in the marine environment. Academic Press, New York, NY, p 65-103

Carpenter EJ, Price CC (1977) Nitrogen fixation, distribution, and production of Oscillatoria (Trichodesmium) spp. in the western Sargasso and Caribbean Seas. Limnol Oceanogr 22:60-72

Chen YB, Zehr JP, Mellon M (1996) Growth and nitrogen fixation of the diazotrophic filamentous nonheterocystous cyanobacterium Trichodesmium sp. IMS 101 in defined media: evidence for a circadian rhythm. J Phycol 32:916-923

> Danovaro R, Luna GM, Dell'Anno A, Pietrangeli B (2006) Comparison of two fingerprinting techniques, terminal restriction fragment length polymorphism and automated ribosomal intergenic spacer analysis, for determination of bacterial diversity in aquatic environments. Appl Environ Microbiol 72:5982-5989

Domingues CM, Maltrud ME, Wijffels SE, Church JA, Tomczak M (2007) Simulated Lagrangian pathways between 
the Leeuwin Current System and the upper-ocean circulation of the southeast Indian Ocean. Deep-Sea Res II 54: 797-817

> Doostmohammadi A, Stocker R, Ardekani AM (2012) LowReynolds-number swimming at pycnoclines. Proc Natl Acad Sci USA 109:3856-3861

> Dugdale RC, Goering JJ (1967) Uptake of new and regenerated forms of nitrogen in primary productivity. Limnol Oceanogr 12:196-206

Eppley RW (1972) Temperature and phytoplankton growth in the sea. Fish Bull 70:1063-1085

Fisher MM, Triplett EW (1999) Automated approach for ribosomal intergenic spacer analysis of microbial diversity and its application to freshwater bacterial communities. Appl Environ Microbiol 65:4630-4636

Fox J, Weisberg S (2009) car: companion to applied regression. R package version 1:2-14. Available at http//cran.rproject-org/web/packages/car/index.html

Fu FX, Mulholland MR, Garcia NS, Beck A, Warner ME, Sanudo-Wilhelmy SA, Hutchins DA (2008) Interactions between changing $\mathrm{pCO}_{2}, \mathrm{~N}_{2}$ fixation, and Fe limitation in the marine unicellular cyanobacterium Crocosphaera. Limnol Oceanogr 53:2472-2484

Garcia NS, Fu FX, Breene CL, Bernhardt PW, Mulholland MR, Sohm JA, Hutchins DA (2011) Interactive effects of irradiance and $\mathrm{CO}_{2}$ on $\mathrm{CO}_{2}$ fixation and $\mathrm{N}_{2}$ fixation in the diazotroph Trichodesmium erythraeum (cyanobacteria). J Phycol 47:1292-1303

Gasol J, Giorgio PD (2000) Using flow cytometry for counting natural planktonic bacteria and understanding the structure of planktonic bacterial communities. Sci Mar 64:197-224

> Gaul W, Antia AN (2001) Taxon-specific growth and selective microzooplankton grazing of phytoplankton in the Northeast Atlantic. J Mar Syst 30:241-261

- Goebel NL, Turk KA, Achilles KM, Paerl R and others (2010) Abundance and distribution of major groups of diazotrophic cyanobacteria and their potential contribution to $\mathrm{N}_{2}$ fixation in the tropical Atlantic Ocean. Environ Microbiol 12:3272-3289

Grasshoff K, Kremling K, Ehrhardt M (eds) (2009) Methods of seawater analysis. Wiley-VCH, Weinheim, p 180-187

> Großkopf T, Mohr W, Baustian T, Schunck H and others (2012) Doubling of marine dinitrogen-fixation rates based on direct measurements. Nature 488:361-364

> Gruber N, Sarmiento JL (1997) Global patterns of marine nitrogen fixation and denitrification. Global Biogeochem Cycles 11:235-266, doi:10.1029/97GB00077

Hamme RC, Emerson SR (2004) The solubility of neon, nitrogen and argon in distilled water and seawater. Deep-Sea Res I 51:1517-1528

Hansen HP, Koroleff F (2009) Determination of nutrients. In: Grasshoff K, Kremling K, Ehrhardt M (eds) Methods of seawater analysis. Wiley-VCH, Weinheim

> Hanson CE, Pattiaratchi CB, Waite AM (2005) Seasonal production regimes off south-western Australia: influence of the Capes and Leeuwin Currents on phytoplankton dynamics. Mar Freshw Res 56:1011-1026

> Hewson I, Fuhrman JA (2004) Richness and diversity of bacterioplankton species along an estuarine gradient in Moreton Bay, Australia. Appl Environ Microbiol 70: 3425-3433

Hillebrand $\mathrm{H}$, Dürselen CD, Kirschtel D, Pollingher U, Zohary T (1999) Biovolume calculation for pelagic and benthic microalgae. J Phycol 35:403-424
Hirata T, Aiken J, Hardman-Mountford N, Smyth T, Barlow $\mathrm{R}$ (2008) An absorption model to determine phytoplankton size classes from satellite ocean colour. Remote Sens Environ 112:3153-3159

> Hood RR, Coles VJ, Capone DG (2004) Modeling the distribution of Trichodesmium and nitrogen fixation in the Atlantic Ocean. J Geophys Res 109:C06006, doi: 10.1029/ 2002JC001753

Hooker SB, Clementson L, Thomas CS, Schlüter L and others (2012) The Fifth SeaWiFS HPLC Analysis RoundRobin Experiment (SeaHARRE-5). NASA Tech Memo 2012-217503

Hutchins D, Fu FX, Zhang Y, Warner M and others (2007) $\mathrm{CO}_{2}$ control of Trichodesmium $\mathrm{N}_{2}$ fixation, photosynthesis, growth rates, and elemental ratios: implications for past, present, and future ocean biogeochemistry. Limnol Oceanogr 52:1293-1304

- Kérouel R, Aminot A (1997) Fluorometric determination of ammonia in sea and estuarine waters by direct segmented flow analysis. Mar Chem 57:265-275

Kokkinakis SA, Wheeler PA (1987) Nitrogen uptake and phytoplankton growth in coastal upwelling regions. Limnol Oceanogr 32:1112-1123

Koslow JA, Pesant S, Feng M, Pearce A and others (2008) The effect of the Leeuwin Current on phytoplankton biomass and production off Southwestern Australia. J Geophys Res 113:C07050, doi:10.1029/2007JC004102

Lessard E (1991) The trophic role of heterotrophic dinoflagellates in diverse marine environments. Mar Microb Food Webs 5:49-58

Letelier RM, Karl DM (1996) Role of Trichodesmium spp. in the productivity of the subtropical North Pacific Ocean. Mar Ecol Prog Ser 133:263-273

Lipschultz F, Bates NR, Carlson CA, Hansell DA (2002) New production in the Sargasso Sea: history and current status. Global Biogeochem Cycles 16:1-1-1-17, doi:10.1029/ 2000GB001319

> Liu H, Dagg M, Campbell L, Urban-Rich J (2004) Picophytoplankton and bacterioplankton in the Mississippi River plume and its adjacent waters. Estuaries 27:147-156

Long JS, Ervin LH (2000) Using heteroscedasticity consistent standard errors in the linear regression model. Am Stat 54:217-224

MacIntyre S, Alldredge AL, Gotschalk CC (1995) Accumulation of marine snow at density discontinuities in the water column. Limnol Oceanogr 40:449-468

Mague T, Weare N, Holm-Hansen O (1974) Nitrogen fixation in the north Pacific Ocean. Mar Biol 24:109-119

Malone TC (1971) The relative importance of nannoplankton and net-plankton as primary producers in tropical oceanic and neritic phytoplankton communities. Limnol Oceanogr 16:633-639

> Marie D, Partensky F, Jacquet S, Vaulot D (1997) Enumeration and cell cycle analysis of natural populations of marine picoplankton by flow cytometry using the nucleic acid stain SYBR Green I. Appl Environ Microbiol 63: 186-193

> Mather RL, Reynolds SE, Wolff GA, Williams RG and others (2008) Phosphorus cycling in the North and South Atlantic Ocean subtropical gyres. Nat Geosci 1:439-443

> McCarthy JJ, Carpenter EJ (1979) Oscillatoria (Trichodesmium) thiebautii (Cyanophyta) in the central north Atlantic Ocean. J Phycol 15:75-82

McKinna LIW, Furnas MJ, Ridd PV (2011) A simple, binary classification algorithm for the detection of Trichodes- 
mium spp. within the Great Barrier Reef using MODIS imagery. Limnol Oceanogr 9:50-66

> McKinnon A, Meekan M, Carleton J, Furnas M, Duggan S, Skirving W (2003) Rapid changes in shelf waters and pelagic communities on the southern Northwest Shelf, Australia, following a tropical cyclone. Cont Shelf Res 23: 93-111

McKinnon AD, Duggan S, Carleton JH, Böttger-Schnack R (2008) Summer planktonic copepod communities of Australia's North West Cape (Indian Ocean) during the 1997-99 El Niño/La Niña. J Plankton Res 30:839-855

Mohr W, Großkopf T, Wallace DW, LaRoche J (2010) Methodological underestimation of oceanic nitrogen fixation rates. PLoS ONE 5:e12583

> Moisander PH, Beinart RA, Hewson I, White AE and others (2010) Unicellular cyanobacteria distributions broaden the oceanic $\mathrm{N}_{2}$ fixation domain. Science 327:1512-1514

> Montoya JP, Voss M, Kahler P, Capone DG (1996) A simple, high-precision, high-sensitivity tracer assay for $\mathrm{N}_{2}$ fixation. Appl Environ Microbiol 62:986-993

Montoya JP, Carpenter EJ, Capone DG (2002) Nitrogen fixation and nitrogen isotope abundances in zooplankton of the oligotrophic North Atlantic. Limnol Oceanogr 47: $1617-1628$

Moore JK, Doney SC (2007) Iron availability limits the ocean nitrogen inventory stabilizing feedbacks between marine denitrification and nitrogen fixation. Global Biogeochem Cycles 21:GB2001

Mulholland MR, Bernhardt PW, Heil CA, Bronk DA, O'Neil JM (2006) Nitrogen fixation and release of fixed nitrogen by Trichodesmium spp. in the Gulf of Mexico. Limnol Oceanogr 51:1762-1776

> Murphy J, Riley J (1962) A modified single solution method for the determination of phosphate in natural waters. Anal Chim Acta 27:31-36

O'Neil JM, Roman MR (1992) Grazers and associated organisms of Trichodesmium. In: Carpenter EJ, Capone DG, Rueter JG (eds) Marine pelagic cyanobacteria: Trichodesmium and other diazotrophs. Springer, Dordrecht, p 61-73

> O'Neil JM, Roman MR (1994) Ingestion of the cyanobacterium Trichodesmium spp. by pelagic harpacticoid copepods Macrosetella, Miracia and Oculosetella. Hydrobiologia 292-293:235-240

> Orcutt KM, Lipschultz F, Gundersen K, Arimoto R, Michaels AF, Knap AH, Gallon JR (2001) A seasonal study of the significance of $\mathrm{N}_{2}$ fixation by Trichodesmium spp. at the Bermuda Atlantic Time-series Study (BATS) site. DeepSea Res II 48:1583-1608

Parsons TR, Maita Y, Lalli CM (1984) Manual of chemical and biological methods for seawater analysis. Pergamon Press, Oxford

> Paterson HL, Knott B, Waite AM (2007) Microzooplankton community structure and grazing on phytoplankton, in an eddy pair in the Indian Ocean off Western Australia. Deep-Sea Res II 54:1076-1093

Paterson H, Heel K, Waite A (2013) A warm-core eddy linking shelf, Leeuwin Current and oceanic waters demonstrated by near-shelf distribution patterns of Synechococcus spp. and Prochlorococcus spp. in the eastern Indian Ocean. Mar Freshw Res 64:1011-1021

Paul D, Skrzypek G, Forizs I (2007) Normalization of measured stable isotope composition to isotope reference scale - a review. Rapid Commun Mass Spectrom 21: 3006-3014
Pearce A, Pattiaratchi CB (1999) The Capes Current: a summer countercurrent flowing past Cape Leeuwin and Cape Naturaliste, Western Australia. Cont Shelf Res 19: 401-420

> Putt M, Stoecker DK (1989) An experimentally determined carbon:volume ratio for marine 'oligotrichous' ciliates from estuarine and coastal waters. Limnol Oceanogr 34: 1097-1103

R Development Core Team (2013) R: a language and environment for statistical computing. R Foundation for Statistical Computing, Vienna

> Ramette A (2009) Quantitative community fingerprinting methods for estimating the abundance of operational taxonomic units in natural microbial communities. Appl Environ Microbiol 75:2495-2505

Redfield AC (1958) The biological control of chemical factors in the environment. Am Sci 46:205-221

> Rees AP, Law CS, Woodward EMS (2006) High rates of nitrogen fixation during an in situ phosphate release experiment in the Eastern Mediterranean Sea. Geophys Res Lett 33:L10607, doi:10.1029/2006GL025791

Ricard M (1987) Atlas du phytoplancton marin. 2: Diatomophycées. CNRS, Paris

Richier S, Macey AI, Pratt NJ, Honey DJ, Moore CM, Bibby TS (2012) Abundances of iron-binding photosynthetic and nitrogen-fixing proteins of Trichodesmium both in culture and in situ from the North Atlantic. PLoS ONE 7: e35571

Rocap G, Distel DL, Waterbury JB, Chisholm SW (2002) Resolution of Prochlorococcus and Synechococcus ecotypes by using 16S-23S ribosomal DNA internal transcribed spacer sequences. Appl Environ Microbiol 68: 1180-1191

Rodier M, Le Borgne R (2008) Population dynamics and environmental conditions affecting Trichodesmium spp. (filamentous cyanobacteria) blooms in the south-west lagoon of New Caledonia. J Exp Mar Biol Ecol 358:20-32

> Rodier M, Le Borgne R (2010) Population and trophic dynamics of Trichodesmium thiebautii in the SE lagoon of New Caledonia. Comparison with T. erythraeum in the SW lagoon. Mar Pollut Bull 61:349-359

Rousseaux CS, Lowe R, Feng M, Waite AM, Thompson PA (2012) The role of the Leeuwin Current and mixed layer depth on the autumn phytoplankton bloom off Ningaloo Reef, Western Australia. Cont Shelf Res 32:22-35

Rubin M, Berman-Frank I, Shaked Y (2011) Dust- and mineral-iron utilization by the marine dinitrogen-fixer Trichodesmium. Nat Geosci 4:529-534

Saito MA, Bertrand EM, Dutkiewicz S, Bulygin VV and others (2011) Iron conservation by reduction of metalloenzyme inventories in the marine diazotroph Crocosphaera watsonii. Proc Natl Acad Sci USA 108:2184-2189

Sigman DM, Altabet MA, Michener R, McCorkle DC, Fry B, Holmes RM (1997) Natural abundance-level measurement of the nitrogen isotopic composition of oceanic nitrate: an adaptation of the ammonia diffusion method. Mar Chem 57:227-242

Sigman DM, Granger J, DiFiore PJ, Lehmann MM, Ho R, Cane G, van Geen A (2005) Coupled nitrogen and oxygen isotope measurements of nitrate along the eastern North Pacific margin. Global Biogeochem Cycles 19: GB4022, doi:10.1029/2005GB002458

Skrzypek G, Sadler R, Paul D (2010) Error propagation in normalization of stable isotope data: a Monte Carlo analysis. Rapid Commun Mass Spectrom 24:2697-2705 
Strathmann RR (1967) Estimating the organic carbon content of phytoplankton from cell volume or plasma volume. Limnol Oceanogr 12:411-418

Subramaniam A, Brown CW, Hood RR, Carpenter EJ, Capone DG (2001) Detecting Trichodesmium blooms in SeaWiFS imagery. Deep-Sea Res II 49:107-121

Suthers I, Rissik D (eds) (2009) Plankton: a guide to their ecology and monitoring for water quality. CSIRO Publishing, Melbourne

Thompson RORY (1984) Observations of the Leeuwin Current off Western Australia. J Phys Oceanogr 14:623-628

Thompson PA, Bonham P, Waite AM, Clementson LA, Cherukuru N, Hassler C, Doblin MA (2011a) Contrasting oceanographic conditions and phytoplankton communities on the east and west coasts of Australia. Deep-Sea Res II 58:645-663

Thompson PA, Wild-Allen K, Lourey M, Rousseaux C, Waite AM, Feng M, Beckley LE (2011b) Nutrients in an oligotrophic boundary current: evidence of a new role for the Leeuwin Current. Prog Oceanogr 91:345-359

Tomas CR, Hasle GR, Syvertsen EE, Steidinger KA, Tangen K, Throndsen J, Heimdal BR (1997) Identifying marine phytoplankton. Academic Press, San Diego, CA

Uitz J, Claustre H, Morel A, Hooker SB (2006) Vertical distribution of phytoplankton communities in open ocean: an assessment based on surface chlorophyll. J Geophys Res 111:C08005, doi:10.1029/2005JC003207

Utermöhl H (1958) Zur Vervollkommnung der quantitativen Phytoplankton-Methodik. Mitt Int Ver Theor Angew Limnol 9:1-38

Vidussi F, Claustre H, Manca BB, Luchetta A, Marty JC (2001) Phytoplankton pigment distribution in relation to upper thermocline circulation in the eastern Mediterranean Sea during winter. J Geophys Res 106:19939-19956

Waite AM, Muhling BA, Holl CM, Beckley LE and others (2007a) Food web structure in two counter-rotating eddies based on $\delta^{15} \mathrm{~N}$ and $\delta^{13} \mathrm{C}$ isotopic analyses. DeepSea Res II 54:1055-1075

Waite AM, Thompson P, Pesant S, Feng $M$ and others (2007b) The Leeuwin Current and its eddies: an introductory overview. Deep-Sea Res II 54:789-796

- Waite AM, Rossi V, Roughan M, Tilbrook B and others (2013) Formation and maintenance of high-nitrate, low $\mathrm{pH}$ layers in the eastern Indian Ocean and the role of nitrogen fixation. Biogeosciences 10:5691-5702

> Wankel SD, Kendall C, Pennington JT, Chavez FP, Paytan A (2007) Nitrification in the euphotic zone as evidenced by nitrate dual isotopic composition: observations from Monterey Bay, California. Global Biogeochem Cycles 21: GB2009, doi:10.1029/2006GB002723

> Wannicke N, Liskow I, Voss M (2010) Impact of diazotrophy on $\mathrm{N}$ stable isotope signatures of nitrate and particulate organic nitrogen: case studies in the north-eastern tropical Atlantic Ocean. Isotopes Environ Health Stud 46: $337-354$

Ward B (2008) Nitrification in marine systems. In: Capone DG, Bronk DA, Mulholland M, Carpenter EJ (eds) Nitrogen in the marine environment, 2nd edn. Elsevier, Amsterdam, p 199-262

Ward B, Kilpatrick K, Renger E, Eppley R (1989) Biological nitrogen cycling in the nitracline. Limnol Oceanogr 34: 493-513

Westberry TK, Siegel DA (2006) Spatial and temporal distribution of Trichodesmium blooms in the world's oceans. Global Biogeochem Cycles 20:GB4016, doi:10.1029/ 2005GB002673

Wijffels S, Sprintall J, Fieux M, Bray N (2002) The JADE and WOCE I10/IR6 throughflow sections in the southeast Indian Ocean. Part 1: Water mass distribution and variability. Deep-Sea Res II 49:1341-1362

> Yool A, Martin AP, Fernández C, Clark DR (2007) The significance of nitrification for oceanic new production. Nature 447:999-1002

Zehr JP, Kudela RM (2011) Nitrogen cycle of the open ocean: from genes to ecosystems. Annu Rev Mar Sci 3:197-225

Zehr JP, Ward BB (2002) Nitrogen cycling in the ocean: new perspectives on processes and paradigms. Appl Environ Microbiol 68:1015-1024

\section{Appendix}

Table A1. Concentration of micronutrients in the YBC II medium and the final micro nutrient additions, when using $2.5 \%$ and $4 \%$ of the enriched YBC II medium, during the bulk $\mathrm{N}_{2}$ fixation and Trichodesmium incubations

\begin{tabular}{|lccc|}
\hline $\begin{array}{l}\text { Micro- } \\
\text { nutrients }\end{array}$ & $\begin{array}{c}\text { YBC II } \\
\text { Medium } \\
\left(\mathrm{mmol} \mathrm{l} \mathrm{l}^{-1}\right)\end{array}$ & $\begin{array}{c}\text { Bulk } \\
\mathrm{N}_{2} \text { fixation } \\
(2.6 \% \text { addition }) \\
(\mathrm{nmol} \mathrm{l})\end{array}$ & $\begin{array}{c}\text { Trichodesmium } \\
\mathrm{N}_{2} \text { fixation } \\
(4 \% \text { addition }) \\
\left(\text { nmol l}^{-1}\right)\end{array}$ \\
\hline $\mathrm{FeCl}_{3} \cdot 6 \mathrm{H}_{2} \mathrm{O}$ & $4.07 \times 10^{-4}$ & 11.0 & 17.0 \\
$\mathrm{MnCl}_{2} \cdot 4 \mathrm{H}_{2} \mathrm{O}$ & $2.00 \times 10^{-5}$ & 0.539 & 0.833 \\
$\mathrm{ZnSO}_{4} \cdot 7 \mathrm{H}_{2} \mathrm{O}$ & $4.00 \times 10^{-6}$ & 0.108 & 0.167 \\
$\mathrm{CoCl}_{2} \cdot 6 \mathrm{H}_{2} \mathrm{O}$ & $2.50 \times 10^{-6}$ & $6.74 \times 10^{-2}$ & 0.104 \\
$\mathrm{Na}_{2} \mathrm{MoO}_{2} \cdot 2 \mathrm{H}_{2} \mathrm{O}$ & $1.10 \times 10^{-5}$ & 0.297 & 0.458 \\
$\mathrm{CuSO}_{4}$ & $1.00 \times 10^{-6}$ & $2.70 \times 10^{-2}$ & $4.17 \times 10^{-2}$ \\
\hline
\end{tabular}

Table A2. Fractional contribution of $\delta^{15} \mathrm{~N}$ from deep $\mathrm{NO}_{3}{ }^{-}$ $(6.6 \pm 0.7 \%)$ and the fractional contribution the $\delta^{15} \mathrm{~N}$ from $\mathrm{N}_{2}$ fixation $(-1.6 \%)$ to the zooplankton size classes. STW: SubTropical Waters, EGC+LC: East Gyral + Leeuwin Current, TS: Timor Sea

\begin{tabular}{|lccc|}
\hline $\begin{array}{l}\text { Water } \\
\text { mass }\end{array}$ & $\begin{array}{c}\text { Size } \\
(\mu \mathrm{m})\end{array}$ & $\begin{array}{c}\text { Fractional contribution } \\
\delta^{15} \mathrm{~N}^{-} \\
\mathrm{Deep} \mathrm{NO}^{-}\end{array}$ & $\begin{array}{c}\delta^{15} \mathrm{~N}- \\
\text { Diazotrophs }\end{array}$ \\
\hline STW $(\mathrm{n}=1)$ & 100 & 0.94 & 0.06 \\
EGC+LC $(\mathrm{n}=3)$ & 100 & $0.98 \pm 0.02$ & $0.02 \pm 0.02$ \\
TS out $(\mathrm{n}=2)$ & 100 & $0.97 \pm 0.04$ & $0.03 \pm 0.04$ \\
TS in $(\mathrm{n}=2)$ & 100 & $0.13 \pm 0.04$ & $0.88 \pm 0.04$ \\
STW $(\mathrm{n}=2)$ & 300 & $0.97 \pm 0.04$ & $0.04 \pm 0.04$ \\
EGC+LC $(\mathrm{n}=3)$ & 300 & $0.99 \pm 0.02$ & $0.01 \pm 0.02$ \\
TS out $(\mathrm{n}=2)$ & 300 & $0.92 \pm 0.10$ & $0.08 \pm 0.10$ \\
TS in $(\mathrm{n}=2)$ & 300 & $0.22 \pm 0.02$ & $0.79 \pm 0.02$ \\
STW $(\mathrm{n}=2)$ & 500 & $0.94 \pm 0.08$ & $0.07 \pm 0.08$ \\
EGC+LC $(\mathrm{n}=3)$ & 500 & $1 \pm 0$ & $0 \pm 0$ \\
TS out $(\mathrm{n}=2)$ & 500 & $0.95 \pm 0.07$ & $0.05 \pm 0.07$ \\
TS in $(\mathrm{n}=2)$ & 500 & $0.53 \pm 0.06$ & $0.47 \pm 0.06$ \\
\hline
\end{tabular}

